\title{
The Environmental Protection Areas tragedy: an analysis of the implementation of Nature Conservation Units, Brazil
}

\author{
A tragédia das Áreas de Proteção Ambiental: uma análise da \\ implementação de Unidades de Conservação da Natureza, Brasil
}

\section{Carlos André Luz Jeronymo'(i), Elmo Rodrigues da Silva' ${ }^{\mathbb{D}}$, Kenny Tanizaki Fonseca"(i)}

' Universidade do Estado do Rio de Janeiro, Rio de Janeiro, RJ, Brazil

"Universidade Federal Fluminense, Rio de Janeiro, RJ, Brazil

\begin{abstract}
The Environmental Protection Area (EPA) is a management category of the Nature Conservation Unit (UC) of the National System of Nature Conservation Units (NSNCU), Brazil. In 2019, it was the third number of management category sites (n. 355) and the largest in extension in the country, with approximately 50\% of the protected coverage of NSNCU. However, there are reports on EPA problems, especially concerning setting and operating their sites. In this paper, we ask, Did the public authorities implant APAs appropriately administrative spheres (federal, state, and municipal) of the public authorities? The hypothesis is that most EPA i) are not implanted. In other words, they are not suitable, enough and ongoing resources, and ii) in completed operation. This article aims to analyze the site's accomplishment of the EPA management category. The methodological procedures involve a literature review, documentary research, and exploratory research from the National Register of Conservation Units (NRCU) and EPA data. In conclusion, none of EPA complies is following NSNCU, and all of them also need to be implanted and managed in degree.
\end{abstract}

Keywords: Environmental Protection Area; Nature Conservation Unit; Environmental Conservation; Protected Areas; National Register of Conservation Units

\section{RESUMO}

A Área de Proteção Ambiental (APA) é uma categoria de manejo de Unidade de Conservação da Natureza (UC) do Sistema Nacional de Unidades de Conservação da Natureza (SNUC), Brasil. Em 2019, ela é a terceira categoria de manejo em número de sítios (n. 355) e a maior em extensão no país, com aproximadamente $50 \%$ da cobertura protegida do SNUC. Todavia, existem relatos sobre problemas que 
envolvem as APA, principalmente no tocante a implantação e funcionamento de seus sítios. Neste trabalho, questiona-se: As APA nas esferas administrativas do poder público (federal, estadual e municipal) foram implementadas de forma adequada? A hipótese é que a maioria das APA não se encontram: i) implantadas, ou seja, com recursos adequados, suficientes e contínuos; e ii) em funcionamento pleno. O objetivo deste trabalho foi analisar a implementação dos sítios da categoria de manejo APA. Os procedimentos metodológicos envolveram uma revisão de literatura, pesquisa documental e uma pesquisa exploratória, com dados do Cadastro Nacional de Unidades de Conservação (CNUC) e outros dados oficiais sobre APA. Como resultado, constatou-se que nenhuma APA está em conformidade com SNUC e todas também carecem de serem implantadas e geridas em algum grau.

Palavras-chave: Área de Proteção Ambiental; Unidade de Conservação da Natureza; Conservação do Ambiente; Área Protegida; Cadastro Nacional de Unidades de Conservação

\section{INTRODUCTION}

The Nature Conservation Units (NCU) are the strict sense protected Brazilian areas that make them equivalent to the International System of the International Union for Conservation of Nature. The NCU is known for its territory, natural resources, and juridical water legally instituted by the Law or the Public Power decree. They must contain biomes, ecosystems, habitat, environments, biodiversity, geodiversity, environmental characteristics, and environmental attributes, aesthetics, or culture that must be considered relevant (BRAZIL, 2000).

The NCU must always focus on protecting the environment through environmental preservation and preserving strategies. Secondly, ecological protection goals are divided into general and specific. The general purpose is determined by the National System of Nature Conservation Units (NSNCU) for each management category. Meanwhile, the specific ones are established in the legal regulation by the NCU creation, its name or denomination, cartographic limits, location, area, management category, Environmental Executive Agency of the Government, economic, security, and national defense activities involved. In addition, the traditional population would be benefited, and reside in specific management categories (BRAZIL, 2000; 2002).

According to Silva, Vieira, and Veras (2014), the existence of an NCU does not necessarily guarantee the achievement of its environmental protection. Not only 
this, but also there is a considerable gap between the creation, implanting, and adequately implementing an NCU in the country, in all management categories.

The implementation is considered a protected site performance as stated in the NSNCU decision and its regulatory decree. As well as the legal framework, national (regulations, ordinances, resolutions, and normative instructions), and international standards to which the country is the attestant.

The focus of this article is the Environmental Protection Areas (EPA). The EPA management category is rated as an NCU by the Sustainable Use group of Brazilian NSNCU. As part of this group, the EPA aims to make nature conservation compatible with the sustainable use of its natural resources (BRAZIL, 2000, pg. 04).

The EPA management category's inherent feature is protecting the usually extensive areas composed of private or public properties. It was made of static environmental or cultural attributes regarding the quality of life and human wealth. It is allowed to use natural resources straightforward and the occupational space in a controlled way. The EPA aims to protect biodiversity, encourage space occupation disciplinary proceedings, ensure sustainable usage, and access to natural resources within its boundaries (BRAZIL, 2000).

According to Bensusan (2006) and WWF (2015), the EPA only exists in legal rules or must be permissive. On the other hand, most of them do not have a Government Council, such as a technical supervisor, a manager, an administrator, a leader, or effective management. Therefore, human action control is ineffective and inefficient to limit human-being activities, against the environmental protection EPA goals.

Accordingly, Artaza-Barrios and Schiavetti (2007) point out that it is crucial for biodiversity protection when an EPA is adequately applied. The authors believe that this management category may become a supporting strategy to maintain natural resources, biodiversity, and several ecosystems in Brazil. However, they do not base their idea on successful cases of EPA implementation or parameters to prove in facts. 
As discussed before throughout this article, It was raised the following question 1. Has the EPA appropriately been applied by the public authorities, such as federal, state, and municipal spheres? The hypothesis is that most EPA is not i) used. In other words, it is not suitable, enough, and ongoing because of the financial, infrastructural, human work, logistics, and ii) in full functioning.

This article's assumption is based on Bensusan's (2006) statement that there is a large quantity of paper EPA due to the public authority's low investment in the site's protection. The concept of Bensusan (2006) is the same as the paper park concept paraphrase or paper-protected areas.

Mulongoy and Chape (2004) stated three levels of Paper Protected Areas or paper parks name.

The first and most crucial level is related to the sites that have never been legally established. The authors say the Government usually announces its intention to create a protected area before installing some rule. The problem is that Government ends up postponing this action indefinitely, and the site was never concluded.

The second level involves protected sites that were created only with a legal regulation but are never applied. There are not only no resources but also no site performance.

The third level presupposes the protected site's full functioning implementation. In accord with the authors, many sites have been poorly designed. They also have non-existent cartographic boundaries, a wrong size, and location, causing fragmented, disconnected, isolated, and small areas. As a result, it becomes a partial, incomplete sample, habitat, and biodiversity or replaced in the wrong place. Nevertheless, as reported by the authors, different levels of inappropriate resources must be considered in the Paper Protected Areas third level regarding adequacy, sufficiency, and continuity.

In general, this article aims to analyze the implementation of the EPA management category and its sites as for the public authorities' administrative 
spheres (federal, state, and municipal). The specific goals are, (i) to raise the deployment settings and to handle EPA management category (ii) to raise the correct data on the deployment settings, pointing out the federal, state, and municipal EPA conduction; (iii) to analyze these data according to the determinators figured out on sites conduction and management in the EPA management category.

This article proves that the EPA represents approximately 15\%number of sites in the NSNCU and $22 \%$ of the number of areas in the Sustainable Use Group, leading the management category to place the third position in the number of NCU in Brazil. The EPA management category covers more than $1.296 .319 \mathrm{~km}^{2}$ $\left(500511,56 \mathrm{mi}^{2}\right)$ of the area, which represents approximately $50 \%$ of the protected coverage of the NSNCU, the largest in territorial extension in Brazil (CADASTRO NACIONAL DE UNIDADES DE CONSERVAÇÃO [NRCU], 2019, Relatório de Dados Consolidados). In addition, EPA sites hold a large quantity of endangered species occurrence and cost-effective increasing in local communities (INSTITUTO CHICO MENDES DE CONSERVAÇÃO DA BIODIVERSIDADE [ICMBIO]; WORLDWIDE FUND FOR NATURE FROM BRAZIL [WWF-BRAZIL], 2012).

The EPA management category sites might influence environmental protection with the proper strategies and implantation in this research. It also contributes towards food and water security, health, and human wealth. It also avoids disasters, poverty, life risks, and climate change. The information produced is expected to assist EPA managers in developing strategies for more efficient management achievement and environmental protection for their sites.

\section{MATERIALS AND METHOD}

This article basement is the hypothetical-deductive method and its deployments (i) Integrative literature review and documentary research; (ii) exploratory research, with secondary data on EPA sites contained in the National 
Register of Conservation Units (NRCU), and on Government NCU Management Agencies official websites (federal, state, and municipal) and other environmental agencies, organs and institutions.

It was also based on websites such as Google Scholar, Scielo portal, the Higher Education Personnel Coordination Improvement portal journal (CAPES), articles, books, and monographs researches (University graduate, postgraduate studies, master, and doctor degree theses), the conference published articles, expert analyses, legal regulations, and official documents. The choice involves not only the literature basing on this research problem, hypothesis, aims, this paper keyword, and research indexers, but also on the creation, implantation, and management of EPA, mainly their full functioning. It took place from March 2015 to April 2019. It was focused.

This research is based on political creation that guides, applies, and manages EPA, focusing on NSNCU, and Decree number 4.340 / 2002, which regulates it. NSNCU is the public policy that creates the Brazilian National System of Protected Areas (NSPA), containing the principles, guidelines, goals, determiners, and instruments for NCU management.

The results involve an EPA sites application evaluation, considering federal, state, and municipal. It also manages categories at the NSNCU level based on the survey and analysis of secondary data and internet sites in the NRCU. The process variables are related to the applied determiners and EPA management included in the NSNCU and its regulatory decree discussed by the documentary research.

The EPA sites data survey in the NRCU supports the methodological procedures in removing the sample (EPA sample) and the query in the Generating NCU Reports (tab ${ }^{1}$ ). In all established the following research parameters: Administrative Sphere, for instance, federal, state, and municipal; NCU management category (EPA) and editors selection (information filed assignment),

\footnotetext{
${ }^{1}$ http://sistemas.mma.gov.br/NRCU/index.php?ido=relatorioparametrizado.exibeFormularioPortal
} 
resulting in a baseline report from the NRCU information compared to all EPA data (dated 04/28/20192). However, one referred to The NRCU Established Data Report $\left(01 / 28 / 2019^{3}\right)$.

The research removed The NRCU sampling period survey data for two reasons:

Brazil has been experiencing conflicts and uncertainties regarding environmental public policies in the last five years. It occurred because of NCU's advance private interests over the community and the ecological supplies checked in Brazil's historic achievements. However, from the new federal government cycle, which began in 2019, many actions or interests were taken to make it more flexible, decreasing, retained, and even breaking off the Environmental Agencies of the government role in the country. The quote mentions:

(i) Breaking or threatening undo national and international agreements, which Brazil is contracting;

(ii) Flex, threaten, or revoke the environmental legislation, mainly decrees, ordinances, resolutions, and normative instructions;

(iii) Attempt to extinguish the Environment Ministry (MMA), or demote it to a Secretariat subordinate to the Agriculture Ministry, contrary to the Stockholm Conference resolutions;

(iv) Trying to merge IBAMA (Environmental Executive Agency of the Government) and ICMBio (Protected Areas Management Agency of the Government), and transform them into just a regulatory agency, with the primary intention of weakening the licensing, and environmental enforcement, and Protected Areas management process that the municipalities decentralized;

(v) Extinguish the Specialized Environment Group of the Public Ministry (Public Prosecutor's Office);

\footnotetext{
2 Municipal: https://drive.google.com/file/d/1qERoaUUHIZZ2TbQQIQXt9W13csCajhjN/view?usp=sharing Estadual: https://drive.google.com/file/d/1yEaDnUyR11YoTQ0JxdDsaTN9EPg9|KKT/view?usp=sharing Federal: https://drive.google.com/file/d/1 mspKoo5J8WLLzIZO3ohuzghXIKZ2IFnp/view?usp=sharing ${ }^{3}$ https://antigo.mma.gov.br/areas-protegidas/cadastro-nacional-de-ucs/dados-consolidados.html
} 
(vi) Cut or freeze fixed or linked budgets, scrap the infrastructures, and work equipment, promote insufficiency, disassemble, and harass human resources. Exonerate specialist employees with a key or managerial positions and replace professionals with no subject or military personnel experience. Authoritatively transfer public servants to distant locations and places with different characteristics of their academic background;

(vii) Promote dismantling, removal of autonomy, and freezing of enforcement actions, and the administrative, procedural sequence of environmental fines. Exonerate public servants from environmental supervisory positions due to the application of penalties, embargoes, seizures, and mischaracterization of assets used in ecological crimes;

(viii) Extinguish, dismantle or weaken environmental public councils, including excluding entities or representatives of organized civil society, with replacement by the military and government representatives, which goes against the parity established by legislation.

(ix) Promote lobbying in-licensing and environmental enforcement, mainly federal. Promote official, and unofficial speeches and discourses, with fake news that (a) encourage the biomes environmental degradation, especially Amazonia and Pantanal, and ecosystems for the illegal advancement of the agricultural frontiers, mineral extraction, and industry activities with potential for polluting or negative environmental impacts; (b) promote an anti-environmental movement, which pits a portion of the population against environmental agencies of the Government, environmental institutions, and environmental protection itself;

(x) approve a law project in the Chamber of Deputies (lower house of the National Congress) that distorts, dismantles, or weakens licensing and enforcement environmental, with, (I) dispensing with environmental licensing from diverse activities and undertakings; (II) creates self-declared environmental licensing with automatic issuance of licenses without prior analysis or enforcement for activities, and undertakings with a low negative environmental impact; (III) ends 
with preliminary licensing; (IV) centralizes decision-making power in the environmental agencies, contrary to the principles of governance, and social participation established by Law, and in the federal constitution; (V) excludes protected areas of indigenous, and Quilombola lands from the analysis of adverse environmental impacts.

All this, to favor the rural elite, and a new progressive project employed the economic growth at any cost in the country, to the detriment of the cost of environmental quality, genetic heritage, biodiversity, climate, agro diversity, traditional communities, small farmers, extractive, and indigenous peoples. Concerning NCU, the discourse is to disaffect sites that contradict these interests and weaken the legislation and the environmental enforcement of these protected sites by encouraging the use and coverage of land in a predatory way.

(2) SARS-Cov-2 pandemic plagues the world, including the paralysis or reduction in the promotion of public services and the action of public agencies, including the environmental portfolio.

The NRCU report used a Google Forms questionnaire and organized tables in a digital spreadsheet editor to support the assessment of the EPA implementation through descriptive statistics in the EPA data. The categorical groups of the analysis were the name of the EPA site, state (s), municipality (s), biome (s), continental or marine areas, IUCN Protected Area category, and public authorities' administrative spheres (federal, state, and municipal).

Subsequently, it compared the data from the NRCU parameterized report with its correspondents on official websites and official documents to verify the adequacy of EPA records. 


\section{RESULTS}

\subsection{Analysis of the implementation of the EPA management category and its protected sites}

The analysis of EPA management category (federal, state, and municipal) (NRCU, 04/28/2019, parameterized report) returned a total of 355 EPA (TABLE 1) ${ }^{4}$ registered and distributed by the conditions of the federation (FIGURE 1$)^{5}$. The state with the most protected sites in this management category is in Rio de Janeiro, whit 73 APAs (20.6\%).

Table 1 - Number of EPA in the public authorities' administrative spheres

\begin{tabular}{lcc}
\hline Administrative Spheres & $\mathbf{N}^{\circ}$. & \% of total \\
\hline Federal & 37 & $10,4 \%$ \\
State & 194 & $54,6 \%$ \\
Municipal & 124 & $34,9 \%$ \\
Total & 355 & \\
\hline
\end{tabular}

Elaborated by the authors (2019). Source: Parameterized Report (NRCU, 28/04/2019)

Figure 1 - Brazil's states of the federation with protected coverage in the form of EPA

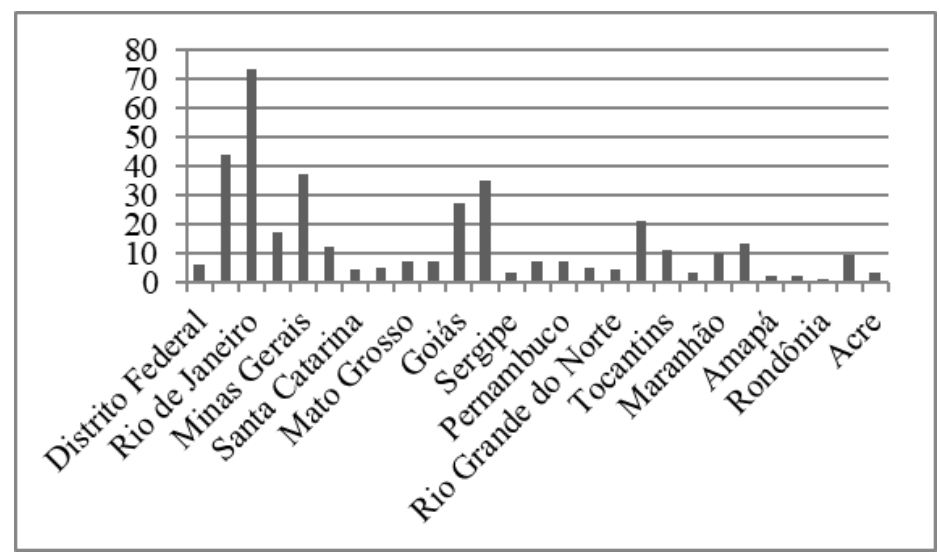

\footnotetext{
${ }^{4}$ Fazenda Capitão Eduardo EPAs was disaffected, that is, its creation was revoked - State Law n ${ }^{\circ} 2.152$ / 2015. Thus, the EPA was removed from the scope of the analysis.

5 There are federal EPA that cover more than one state of the federation.
} 
Elaborated by the authors (2019). Source: Parameterized Report (NRCU, 28/04/2019).

A search on official websites (NCU Management Agencies of the Government) of the public authorities' administrative spheres showed that there is EPA not yet registered in the NRCU. However, it was not possible to quantify them.

It noted analysis that the parameterized report from the NRCU only provides information from one biome per EPA, whether it is continental or marine. In consultation with the official websites, there are EPA that cover more than one biome, and some of them are partly continental and partly marine. As a result, it was impossible to calculate the number of EPA per biome and per continental or oceanic environment using the parameterized report data. To this end, the data usage provided in the consolidated data report of the NRCU, that is, data from certified registrations dated 01/28/2019.

Table 2 shows the number of protected sites in the EPA management category by biome, marine, or continental environment, the percentage of protected coverage in each biome, and protected marine and continental range.

Table 2 - The number of protected sites in the EPA management category per biome, the percentage of protected coverage for each biome, and protected marine or continental range

\begin{tabular}{lccc}
\hline Biomes & $\mathbf{N}^{\mathbf{0}}$ & Area $\left.\mathbf{( k m}^{\mathbf{2}}\right)$ & $\%$ \\
\hline Amazon & 40 & 204.022 & $4,9 \%$ \\
Caatinga & 37 & 58.329 & $7,0 \%$ \\
Cerrado & 77 & 109.873 & $5,4 \%$ \\
Atlantic Forest & 216 & 84.750 & $7,6 \%$ \\
Pampa & 4 & 4.443 & $2,5 \%$ \\
Pantanal & 0 & 0 & $0,0 \%$ \\
Continental & 341 & 461.418 & $5,4 \%$ \\
Marine & 72 & 834.901 & $22,9 \%$ \\
\hline
\end{tabular}

Source: NRCU Consolidated Data Report of 01/28/2019. 
Table 2 reveals that most EPA is found in the Atlantic Forest biome and is continental. The biome with the highest percentage of protected coverage is also the Atlantic Forest. Despite having a smaller number of EPA, the marine environment has a proportionally protected range than the continental environment.

Table 3 shows the protected coverage in the form of EPA, in hectares, according to data from the parameterized report of the NRCU and the official websites.

Table 3 - The protected coverage in the form of EPA

\begin{tabular}{lcccccc}
\hline EPA & NRCU (ha) & \% & Official Website (ha) & \% & Consolidated data (ha) & \% \\
\hline Federal & $91.514 .668,0$ & $70,4 \%$ & $77.091 .900,0$ & $55,6 \%$ & 89.722 .000 & $69,2 \%$ \\
State & $32.128 .034,8$ & $24,7 \%$ & $48.868 .883,5$ & $35,3 \%$ & 34.067 .100 & $26,3 \%$ \\
Municipal & $6.335 .194,9$ & $4,9 \%$ & $12.632 .316,9$ & $9,1 \%$ & 5.842 .800 & $4,5 \%$ \\
Total & $129.977 .897,6$ & & $138.593 .100,4$ & & $129.631 .900,0$ & \\
\hline
\end{tabular}

Elaborated by the authors (2019). Source: Parameterized Report (NRCU, 28/04/2019); official websites of NCU Management Agencies of the Government.

The comparison of the data (Table 3) reveals inconsistencies in the area values between NRCU and the NCU Management Agencies of the Government.

Table 4 shows an analysis made to identify where the inconsistencies in the EPA coverage data are located.

Table 4 - Comparison between the area information of the EPA between NRCU and official websites

\begin{tabular}{lcccccccc}
\hline $\begin{array}{l}\text { Area's data } \\
\text { counterproof }\end{array}$ & $\mathbf{N}^{\circ}$. & Total \% & $\begin{array}{c}\text { Federal } \\
\left(\mathbf{n}^{\circ} .\right)\end{array}$ & $\begin{array}{c}\text { federal } \\
\text { total \% }\end{array}$ & $\begin{array}{c}\text { State } \\
\left(\mathbf{n}^{\circ} .\right)\end{array}$ & $\begin{array}{c}\text { state } \\
\text { total \% }\end{array}$ & $\begin{array}{c}\text { Municip } \\
\text { al }\left(\mathbf{n}^{\circ} .\right)\end{array}$ & $\begin{array}{c}\text { municipal } \\
\text { total \% }\end{array}$ \\
\hline Match & 93 & $26,2 \%$ & 4 & $10,8 \%$ & 71 & $36,6 \%$ & 18 & $14,5 \%$ \\
Doesn't Match & 215 & $60,6 \%$ & 30 & $81,1 \%$ & 118 & $60,8 \%$ & 67 & $54,0 \%$ \\
\hline
\end{tabular}


Table 4 - Conclusion

\begin{tabular}{lcccccccc}
\hline $\begin{array}{l}\text { Area's data } \\
\text { counterproof }\end{array}$ & $\mathbf{N}^{\circ}$. & Total \% & $\begin{array}{c}\text { Federal } \\
\left(\mathbf{n}^{\circ} .\right)\end{array}$ & $\begin{array}{c}\text { federal } \\
\text { total \% }\end{array}$ & $\begin{array}{c}\text { State } \\
\left(\mathbf{n}^{\circ} .\right)\end{array}$ & $\begin{array}{c}\text { state } \\
\text { total \% }\end{array}$ & $\begin{array}{c}\text { Municipal } \\
\left(\mathbf{n}^{\circ} .\right)\end{array}$ & $\begin{array}{c}\text { municipal } \\
\text { total \% }\end{array}$ \\
\hline $\begin{array}{l}\text { Exist only on } \\
\text { official websites }\end{array}$ & 7 & $2 \%$ & 3 & $8,1 \%$ & 4 & $2,0 \%$ & 0 & $0,0 \%$ \\
$\begin{array}{l}\text { Couldn't verify } \\
\text { Total }\end{array}$ & 30 & $11,3 \%$ & 0 & $0,0 \%$ & 1 & $0,5 \%$ & 39 & $31,4 \%$ \\
\hline
\end{tabular}

Elaborated by the authors (2019). Source: Parameterized Report (NRCU, 28/04/2019); official websites of NCU Management Agencies of the Government.

Table 4 reveals that 215 EPA $(60.6 \%)$ has an area that does not coincide with the parameterized report of the NRCU and the official websites. Nevertheless, the research found the following data:

a) 128 EPA (36.0\%) does not have a polygon area (georeferenced data) inserted in the NRCU, but an area estimate;

b) 227 EPA (64\%) claim to has georeferenced data corresponding to the descriptive memorial of the legal creation regulation. However, they all return an area value of "0" according to the polygon (.shp) inserted in the NRCU. Thus, there is uncertainty about coverage area and localization data.

Figure 2 shows the number of EPA created in the period between 1982-2019.

Figure 2 - Number of EPA created in the period between 1982-2019.

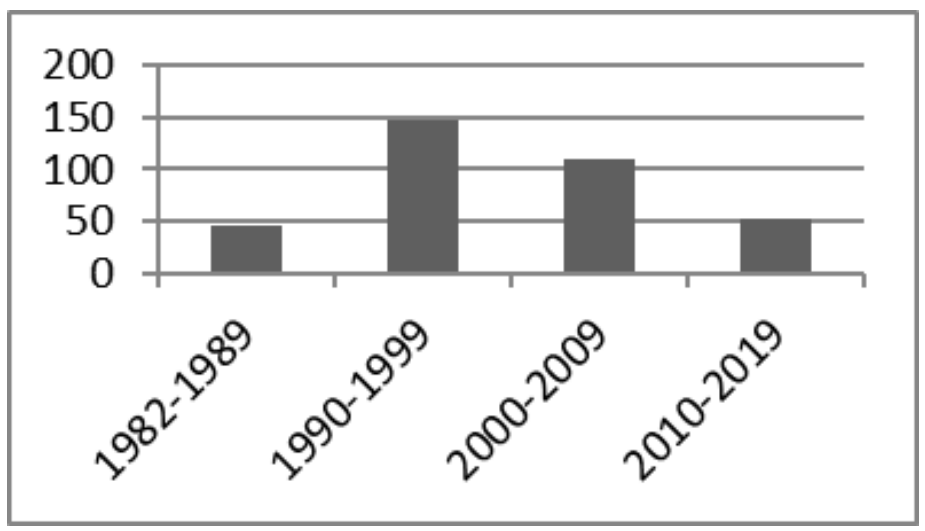

Elaborated by the authors (2019). Source: Parameterized Report (NRCU, 28/04/2019). 
The first EPA was created on 09/13/1982 - EPA Petrópolis (RJ). The authors created it in the 1990s with a drop in the creation of protected sites in subsequent decades. In 2018, 17 One created EPA. In 2019, until April 28, there was no creation of any more EPA (FIGURE 2).

Table 5 shows the year of the last certification of the EPA registered on NRCU (2007-2019). The base year of 2007 refers to the implantation of the NRCU.

Table 5 - The year of the last certification of the EPA registered on NRCU (2007-2019)

\begin{tabular}{|c|c|c|c|c|c|c|c|c|}
\hline $\begin{array}{l}\text { Last } \\
\text { certification } \\
\text { (year) }\end{array}$ & $\mathbf{N}^{\circ}$. & $\begin{array}{c}\text { Total } \\
\%\end{array}$ & $\begin{array}{c}\text { Federal } \\
\left(n^{\circ} .\right)\end{array}$ & $\begin{array}{l}\text { federal } \\
\text { total \% }\end{array}$ & $\begin{array}{c}\text { State } \\
\left(n^{\circ} .\right)\end{array}$ & $\begin{array}{c}\text { state } \\
\text { total \% }\end{array}$ & $\begin{array}{c}\text { Municipal } \\
\left(n^{\circ} .\right)\end{array}$ & $\begin{array}{c}\text { municipal } \\
\text { total \% }\end{array}$ \\
\hline 2007 & 26 & $7,3 \%$ & 8 & $21,6 \%$ & 16 & $8,2 \%$ & 2 & $1,6 \%$ \\
\hline 2008 & 4 & $1,1 \%$ & 1 & $2,7 \%$ & 3 & $1,5 \%$ & 0 & $0,0 \%$ \\
\hline 2009 & 15 & $4,2 \%$ & 1 & $2,7 \%$ & 13 & $6,7 \%$ & 1 & $0,8 \%$ \\
\hline 2010 & 26 & $7,3 \%$ & 14 & $37,8 \%$ & 9 & $4,6 \%$ & 3 & $2,4 \%$ \\
\hline 2011 & 59 & $16,6 \%$ & 5 & $13,5 \%$ & 27 & $13,9 \%$ & 27 & $21,8 \%$ \\
\hline 2012 & 50 & $14,0 \%$ & 0 & $0,0 \%$ & 34 & $17,5 \%$ & 16 & $12,9 \%$ \\
\hline 2013 & 11 & $3,1 \%$ & 0 & $0,0 \%$ & 3 & $1,5 \%$ & 8 & $6,4 \%$ \\
\hline 2014 & 19 & $5,3 \%$ & 0 & $0,0 \%$ & 7 & $3,6 \%$ & 12 & $9,7 \%$ \\
\hline 2015 & 19 & $5,3 \%$ & 1 & $2,7 \%$ & 15 & $7,7 \%$ & 3 & $2,4 \%$ \\
\hline 2016 & 40 & $11,3 \%$ & 2 & $5,4 \%$ & 35 & $18,0 \%$ & 3 & $2,4 \%$ \\
\hline 2017 & 33 & $9,3 \%$ & 1 & $2,7 \%$ & 18 & $9,2 \%$ & 14 & $11,3 \%$ \\
\hline 2018 & 34 & $9,6 \%$ & 4 & $10,8 \%$ & 9 & $4,6 \%$ & 21 & $16,9 \%$ \\
\hline 2019 & 19 & $5,3 \%$ & 0 & $0,0 \%$ & 5 & $2,6 \%$ & 14 & $11,3 \%$ \\
\hline Total & 355 & & 37 & & 194 & & 124 & \\
\hline
\end{tabular}

Elaborated by the authors (2019). Source: Parameterized Report (NRCU, 28/04/2019).

The data crossing of the creation data (FIGURE 4) with the last certification data (TABLE 5) revealed that (i) until 2009, only 35 EPA had registered on NRCU, and there were exists at least 302 EPA in that year, according to the dates of NCU creation contained itself in 2019; (ii) 30 EPA (8\%) are certified for last ten years or more; (iii) 199 EPA (56\%) are certified for last five years or more; and (iv) 83 EPA 
(23.3\%) are certified for last two years or less, and (v) only 23 of these were created and certified between 2016, and 2018.

The information reveals an initial non-adherence to the NRCU, which the EPA managers promote that adherence over the years in a dissolved manner. Also, most registered EPA has data with old certification or more significant than a cycle of a Management Council (Governance and social participation Institution) - two years. Aside from that, there are EPA not yet registered on NRCU.

Table 6 shows the number of EPA with the team head (technical supervisor), according to the parameterized report from the NRCU.

Table 6: Number of EPA with team head (NRCU)

\begin{tabular}{|c|c|c|c|c|c|c|c|c|}
\hline Team head & $\mathbf{N}^{\circ}$. & $\begin{array}{c}\text { Total } \\
\%\end{array}$ & $\begin{array}{c}\text { Federal } \\
\left(n^{\circ} .\right)\end{array}$ & $\begin{array}{c}\text { federal } \\
\text { total } \\
\%\end{array}$ & $\begin{array}{c}\text { State } \\
\left(n^{\circ} .\right)\end{array}$ & $\begin{array}{c}\text { state } \\
\text { total } \\
\%\end{array}$ & $\begin{array}{c}\text { Municipal } \\
\left(n^{\circ} .\right)\end{array}$ & $\begin{array}{c}\text { municipal } \\
\text { total } \\
\%\end{array}$ \\
\hline Has & 115 & $32,4 \%$ & 29 & $78,4 \%$ & 82 & $42,3 \%$ & 4 & $3,2 \%$ \\
\hline $\begin{array}{l}\text { Doesn't } \\
\text { have }\end{array}$ & 112 & $31,5 \%$ & 0 & $0,0 \%$ & 112 & $57,7 \%$ & 0 & $0,0 \%$ \\
\hline $\begin{array}{l}\text { Doesn't } \\
\text { have } \\
\text { information }\end{array}$ & 128 & $36,1 \%$ & 8 & $21,6 \%$ & 0 & $0,0 \%$ & 120 & $96,8 \%$ \\
\hline Total & 355 & & 37 & & 194 & & 124 & \\
\hline
\end{tabular}

Elaborated by the authors (2019). Source: Parameterized Report (NRCU, 28/04/2019).

Table 6 reveals that 115 EPA (32.3\%) has a supervisor, 112 EPA (31.5\%) does not have, and the existence of a supervisor in 128 EPA (36.0\%) is uncertain. It attempted to investigate on the official websites whether the EPA has a team head or not to verify the adequacy of the data obtained in the parameterized report of the NRCU and try to remedy the uncertainty of the 128 EPA mentioned above.

Table 7 shows the data crossing between the parameterized report of the NRCU and official websites. 
Table 7 - Number of EPA with team head

\begin{tabular}{|c|c|c|c|c|c|c|c|c|}
\hline $\begin{array}{l}\text { Team } \\
\text { head }\end{array}$ & $\mathbf{N}^{\circ}$ & $\begin{array}{c}\text { Total } \\
\%\end{array}$ & $\begin{array}{c}\text { Federal } \\
\left(n^{\circ} .\right)\end{array}$ & $\begin{array}{l}\text { federal } \\
\text { total } \%\end{array}$ & $\begin{array}{l}\text { State } \\
\left(\mathrm{n}^{\circ} .\right)\end{array}$ & $\begin{array}{c}\text { state total } \\
\%\end{array}$ & $\begin{array}{l}\text { Municipal } \\
\left(n^{\circ} .\right)\end{array}$ & $\begin{array}{c}\text { municipal } \\
\text { total } \%\end{array}$ \\
\hline Has & 124 & $34,9 \%$ & 30 & $81,1 \%$ & 93 & $47,9 \%$ & 1 & $0,8 \%$ \\
\hline $\begin{array}{l}\text { Doesn't } \\
\text { have }\end{array}$ & 96 & $27,0 \%$ & 5 & $13,5 \%$ & 76 & $39,9 \%$ & 15 & $12,1 \%$ \\
\hline $\begin{array}{l}\text { Couldn't } \\
\text { verify }{ }^{6}\end{array}$ & 135 & $38,0 \%$ & 2 & $5,4 \%$ & 25 & $12,9 \%$ & 108 & $87,1 \%$ \\
\hline Total & & 355 & & & & 37 & & \\
\hline
\end{tabular}

Elaborated by the authors (2019). Source: Parameterized Report (NRCU, 28/04/2019); official websites of NCU Management Agencies of the Government.

Table 7 revealed that 124 EPA (34.9\%) has team heads, 96 EPA (27\%) does not have, and the existence of them in 135 EPA (38.0\%) is uncertain. It reveals that protected sites number without supervisors and the uncertainty about their presence in EPA are still high. The lack of data occurs almost entirely in the municipal administrative sphere, as in Table 6.

Table 8 shows the number of EPA with a Management Council, according to the parameterized report from the NRCU.

Table 8 - Number of EPA with the Management Council (NRCU)

\begin{tabular}{lcccccccc}
\hline $\begin{array}{l}\text { Management } \\
\text { Council }\end{array}$ & $\mathbf{N}^{\mathbf{0}}$. & Total \% & $\begin{array}{c}\text { Federal } \\
\left(\mathbf{n}^{\circ} . \mathbf{)}\right.\end{array}$ & $\begin{array}{c}\text { federal } \\
\text { total \% }\end{array}$ & $\begin{array}{c}\text { State } \\
\left(\mathbf{n}^{\circ} . \mathbf{)}\right.\end{array}$ & $\begin{array}{c}\text { state } \\
\text { total \% }\end{array}$ & $\begin{array}{c}\text { Municipal } \\
\left(\mathbf{n}^{\circ} \text {.) }\right.\end{array}$ & $\begin{array}{c}\text { municipal } \\
\text { total \% }\end{array}$ \\
\hline Has & 161 & $45,3 \%$ & 24 & $64,9 \%$ & 91 & $46,9 \%$ & 46 & $37,1 \%$ \\
Doesn't have & 194 & $54,6 \%$ & 13 & $35,1 \%$ & 103 & $53,1 \%$ & 78 & $62,9 \%$ \\
Total & 355 & & 37 & & 194 & & 124 & \\
\hline
\end{tabular}

Elaborated by the authors (2019). Source: Parameterized Report (NRCU, 28/04/2019).

Table 8 reveals that 194 EPA (54.6\%) does not have a Management Council, which is worse in the municipal administered and more moderate in the federal

\footnotetext{
${ }^{6}$ There are team leads according to the NRCU, but it was not possible to verify if they are still ahead of the EPA management or if there is anyone in front of the administration.
} 
ones. It attempted to investigate whether the EPA has a Management Council or not on the official websites to verify the adequacy of the data obtained in the parameterized report of the NRCU.

Table 9 shows the data crossing between the parameterized report of the NRCU and official websites.

Table 9 - Number of EPA with a Management Council

\begin{tabular}{lcccccccc}
\hline $\begin{array}{l}\text { Management } \\
\text { Council }\end{array}$ & $\mathbf{N}^{\circ}$. & Total \% & $\begin{array}{c}\text { Federal } \\
\left(\mathbf{n}^{\circ} .\right)\end{array}$ & $\begin{array}{c}\text { federal } \\
\text { total } \%\end{array}$ & State $\left(\mathbf{n}^{\circ} . \mathbf{)}\right.$ & $\begin{array}{c}\text { state total } \\
\mathbf{\%}\end{array}$ & $\begin{array}{c}\text { Municipal } \\
\left(\mathbf{n}^{\circ} .\right)\end{array}$ & $\begin{array}{c}\text { municipal } \\
\text { total \% }\end{array}$ \\
\hline Has & 175 & $49,3 \%$ & 27 & $73 \%$ & 118 & $60,8 \%$ & 30 & $24,2 \%$ \\
Doesn't have & 77 & $21,7 \%$ & 10 & $27 \%$ & 2 & $1 \%$ & 65 & $52,4 \%$ \\
Couldn't verify & 103 & $29,0 \%$ & 0 & $0,0 \%$ & 74 & $38,1 \%$ & 29 & $23,4 \%$ \\
Total & 355 & & 37 & & 194 & & 124 & \\
\hline
\end{tabular}

Elaborated by the authors (2019). Source: Parameterized Report (NRCU, 28/04/2019); official websites of NCU Management Agencies of the Government.

Table 9 reveals that 175 EPA (49.3\%) has a Management Council, and 103 EPA (29\%) does not have this information on their official Website, a scenario little different from that revealed by the parameterized report of the NRCU.

The Management Councils' Internal Regiment existence, including EPA, did not include the document in the framework of Legal Acts of the NCU on NRCU. Therefore, it was not possible to analyze the parameterized report. There was a search on the Management Councils' Internals Regiment existence on the official websites in this concept.

Table 10 shows the number of EPA with the internal regiment for the Management Council. 
Table 10 - Number of EPA with an Internal Regiment of the Management Council

\begin{tabular}{lcccccccc}
\hline $\begin{array}{l}\text { Internal } \\
\text { regiment }\end{array}$ & $\mathbf{N}^{\circ}$. & $\begin{array}{c}\text { Total } \\
\%\end{array}$ & $\begin{array}{c}\text { Federal } \\
\left(\mathbf{n}^{\circ} .\right)\end{array}$ & $\begin{array}{c}\text { federal } \\
\text { total \% }\end{array}$ & $\begin{array}{c}\text { State } \\
\left(\mathbf{n}^{\circ} .\right)\end{array}$ & $\begin{array}{c}\text { state } \\
\text { total \% }\end{array}$ & $\begin{array}{c}\text { Municipal } \\
\left(\mathbf{n}^{\circ} .\right)\end{array}$ & $\begin{array}{c}\text { municipal } \\
\text { total \% }\end{array}$ \\
\hline $\begin{array}{l}\text { Has Internal } \\
\text { regiment }\end{array}$ & 99 & $27,9 \%$ & 0 & $0,0 \%$ & 87 & $44,8 \%$ & 12 & $9,7 \%$ \\
$\begin{array}{l}\text { Doesn't have } \\
\text { an internal } \\
\text { regiment }\end{array}$ & 66 & $18,6 \%$ & 27 & $73 \%$ & 30 & $15,5 \%$ & 9 & $7,3 \%$ \\
$\begin{array}{l}\text { Doesn't have } \\
\text { Management }\end{array}$ & 157 & $44,2 \%$ & 10 & $27 \%$ & 73 & $37,6 \%$ & 74 & $59,7 \%$ \\
$\begin{array}{l}\text { Council } \\
\text { Couldn't verify }\end{array}$ & 33 & $9,3 \%$ & 0 & $0,0 \%$ & 4 & $2,1 \%$ & 29 & $23,4 \%$ \\
Total & 355 & & 37 & & 194 & & 124 & \\
\hline
\end{tabular}

Elaborated by the authors (2019). Source: official websites of NCU Management Agencies of the Government.

Table 10 reveals that only 99 EPA (27.9\%) has a Management Council with an internal regiment, and it is not possible to show the case in 33 EPA (9.3\%). The lack of an interior company affects the way the Management Council works and their representatives actuation, which undermines governance, and social participation, in this case in most of the EPA (at least 62.8\%)

Table 11 shows the number of EPA with a Management Plan, according to the parameterized report from the NRCU.

Table 11 - Number of EPA with Management Plan (NRCU)

\begin{tabular}{|c|c|c|c|c|c|c|c|c|}
\hline $\begin{array}{l}\text { Management } \\
\text { Plan }\end{array}$ & $\mathbf{N}^{\circ}$. & $\begin{array}{l}\text { Total } \\
\%\end{array}$ & $\begin{array}{l}\text { Federal } \\
\left(n^{\circ} .\right)\end{array}$ & $\begin{array}{l}\text { federal } \\
\text { total \% }\end{array}$ & $\begin{array}{l}\text { State } \\
\left(n^{\circ} .\right)\end{array}$ & $\begin{array}{c}\text { state total } \\
\%\end{array}$ & $\begin{array}{c}\text { Municipal } \\
\left(n^{\circ} .\right)\end{array}$ & $\begin{array}{c}\text { municipal } \\
\text { total \% }\end{array}$ \\
\hline Has & 68 & $19,1 \%$ & 5 & $13,5 \%$ & 44 & $22,7 \%$ & 19 & $15,3 \%$ \\
\hline Doesn't have & 287 & $80,8 \%$ & 32 & $86,5 \%$ & 150 & $77,3 \%$ & 105 & $84,7 \%$ \\
\hline Total & 355 & & 37 & & 194 & & 124 & \\
\hline
\end{tabular}

Elaborated by the authors (2019). Source: Parameterized Report (NRCU, 28/04/2019).

Table 11 reveals that only 68 EPA (19.1\%) have the Management Plan, a document guiding these UCs. It attempted to investigate whether the EPA has a 
Management Plan or not on the official websites to verify the adequacy of the data obtained in the parameterized report of the NRCU.

Table 12 shows the EPA Management Plan existence data crossing according to the parameterized report of the NRCU and the search of the official websites.

Table 12 - Number of EPA with Management Plan

\begin{tabular}{lcccccccc}
\hline $\begin{array}{l}\text { Management } \\
\text { Plan }\end{array}$ & $\mathbf{N}^{\circ}$. & $\begin{array}{c}\text { Total } \\
\mathbf{\%}\end{array}$ & $\begin{array}{c}\text { Federal } \\
\left(\mathbf{n}^{\circ} \mathbf{.}\right)\end{array}$ & $\begin{array}{c}\text { federal } \\
\text { total \% }\end{array}$ & $\begin{array}{c}\text { State } \\
\left(\mathbf{n}^{\circ} \text {.) }\right.\end{array}$ & $\begin{array}{c}\text { state } \\
\text { total \% }\end{array}$ & $\begin{array}{c}\text { Municipal } \\
\left(\mathbf{n}^{\circ} \text {.) }\right.\end{array}$ & $\begin{array}{c}\text { municipal } \\
\text { total \% }\end{array}$ \\
\hline Has & 85 & $23,9 \%$ & 16 & $43,2 \%$ & 52 & $26,8 \%$ & 17 & $13,7 \%$ \\
Doesn't have & 251 & $70,7 \%$ & 21 & $56,8 \%$ & 142 & $73,2 \%$ & 88 & $71 \%$ \\
Couldn't verify & 19 & $5,3 \%$ & 0 & $0,0 \%$ & 0 & $0,0 \%$ & 19 & $15,3 \%$ \\
Total & 355 & & 37 & & 194 & & 124 & \\
\hline
\end{tabular}

Elaborated by the authors (2019). Source: Parameterized Report (NRCU, 28/04/2019); official websites of NCU Management Agencies of the Government.

Table 12 reveals that 85 EPA (23.9\%) has a Management Plan, a higher number than the parameterized report from the NRCU, but still low. All EPA did not include the Management Plan in the framework of Legal Acts of the NCU on NRCU. They also did not have the Management Plan regulation. The NRCU does not inform the possibility revision phase platform in which the Management Plan is in, nor is it regulated. Thus, according to official websites, It carried out EPA Management Plans phases and regulations analysis.

Table 13 shows the Management Plans Phases. 
Table 13 - Phases of the Management Plans of the EPA

\begin{tabular}{lcccccccc}
\hline $\begin{array}{l}\text { Management } \\
\text { Plans Phases }\end{array}$ & $\mathbf{N}^{\circ}$. & Total \% & $\begin{array}{c}\text { Federal } \\
\left(\mathbf{n}^{\circ} . \mathbf{}\right)\end{array}$ & $\begin{array}{c}\text { federal } \\
\text { total \% }\end{array}$ & $\begin{array}{c}\text { State } \\
\left(\mathbf{n}^{\circ} . \mathbf{}\right)\end{array}$ & $\begin{array}{c}\text { state } \\
\text { total \% }\end{array}$ & $\begin{array}{c}\text { Municipal } \\
\left(\mathbf{n}^{\circ} . \mathbf{}\right)\end{array}$ & $\begin{array}{c}\text { municipal } \\
\text { total \% }\end{array}$ \\
\hline Phase 1 & 29 & $8,8 \%$ & 2 & $5,4 \%$ & 18 & $9,3 \%$ & 9 & $7,3 \%$ \\
Phase 2 & 21 & $5,9 \%$ & 0 & $0,0 \%$ & 17 & $8,8 \%$ & 4 & $3,2 \%$ \\
Phase 3 & 18 & $5,1 \%$ & 10 & $27,0 \%$ & 6 & $3,1 \%$ & 2 & $1,6 \%$ \\
Phase + & 6 & $1,7 \%$ & 4 & $10,8 \%$ & 2 & $1 \%$ & 0 & $0,0 \%$ \\
Doesn't have & 251 & $70,7 \%$ & 21 & $56,8 \%$ & 142 & $73,2 \%$ & 88 & $71 \%$ \\
Couldn't verify & 30 & $8,4 \%$ & 0 & $0,0 \%$ & 9 & $4,6 \%$ & 21 & $16,9 \%$ \\
Total & 355 & & 37 & $115,6 \%$ & 194 & & 124 & \\
\hline
\end{tabular}

Elaborated by the authors (2019). Source: official websites of NCU Management Agencies of the Government.

Table 14 reveals the EPA Management Plans regulation.

Table 14 - Regulamentation of EPA Management Plans

\begin{tabular}{lcccccccc}
\hline $\begin{array}{l}\text { Management } \\
\begin{array}{l}\text { Plan } \\
\text { regulamentation }\end{array}\end{array}$ & $\mathbf{N}^{\circ}$. & $\begin{array}{c}\text { Total } \\
\%\end{array}$ & $\begin{array}{c}\text { Federal } \\
\left(\mathbf{n}^{\circ} .\right)\end{array}$ & $\begin{array}{c}\text { federal } \\
\text { total \% }\end{array}$ & $\begin{array}{c}\text { State } \\
\left(\mathbf{n}^{\circ} .\right)\end{array}$ & $\begin{array}{c}\text { state } \\
\text { total \% }\end{array}$ & $\begin{array}{c}\text { Municipal } \\
\left(\mathbf{n}^{\circ} . \mathbf{}\right)\end{array}$ & $\begin{array}{c}\text { municipal } \\
\text { total \% }\end{array}$ \\
\hline Has & 34 & $9,6 \%$ & 4 & $10,8 \%$ & 22 & $11,3 \%$ & 8 & $6,4 \%$ \\
$\begin{array}{l}\text { Doesn't have } \\
\text { regulamentation }\end{array}$ & 47 & $13,2 \%$ & 12 & $32,4 \%$ & 28 & $14,4 \%$ & 7 & $5,6 \%$ \\
$\begin{array}{l}\text { Doesn't have } \\
\text { Management Plan }\end{array}$ & 251 & $70,7 \%$ & 21 & $56,8 \%$ & 142 & $73,2 \%$ & 88 & $71 \%$ \\
$\begin{array}{l}\text { Couldn't verify } \\
\text { Total }\end{array}$ & 23 & $6,5 \%$ & 0 & $0,0 \%$ & 2 & $1 \%$ & 21 & $16,9 \%$ \\
\hline
\end{tabular}

Elaborated by the authors (2019). Source: official websites of NCU Management Agencies of the Government.

From the two analyzes, it was possible to verify the current phase of the Management Plan in only 74 EPA (20.8\%) (TABLE 13). Regarding the regulation of the Management Plan, only 34 EPA (9.6\%) has the legal act of code (TABLE 14). A Management Plan prepared, approved, and at an appropriate stage is essential for the administration of EPA since it is the guiding principle for the management of 
category, and its protected sites, apart from its programmatic dimension and planning bias. The regulation of the Management Plan is essential because of its normative dimension. As a result, more than $90 \%$ of EPA does not have determinations for controlling the occupation of space or the use and access to natural resources.

The EPA must have other management instruments; the Environmental Zoning is the only mandatory according to NSNCU and its Decree $n^{\circ} .4 .340 / 2002$. The parameterized report of the NRCU has an item that informs the existence of other instruments for management. However, he does not say what these would be, nor does he provide the documents in the framework of the legal acts.

Table 15 shows the number of EPA with other management tools, according to the parameterized report from the NRCU.

Table 15 - Number of EPA with other management instruments (NRCU)

\begin{tabular}{lcccccccc}
\hline $\begin{array}{l}\text { Other } \\
\text { management } \\
\text { tools }\end{array}$ & $\mathbf{N}^{\circ}$. & Total \% & $\begin{array}{c}\text { Federal } \\
\left(\mathbf{n}^{\circ} .\right)\end{array}$ & $\begin{array}{c}\text { federal } \\
\text { total \% }\end{array}$ & $\begin{array}{c}\text { State } \\
\left(\mathbf{n}^{\circ} .\right)\end{array}$ & $\begin{array}{c}\text { state } \\
\text { total \% }\end{array}$ & $\begin{array}{c}\text { Municipal } \\
\left(\mathbf{n}^{\circ} .\right)\end{array}$ & $\begin{array}{c}\text { municipal } \\
\text { total \% }\end{array}$ \\
\hline Has & 119 & $33,5 \%$ & 10 & $27,0 \%$ & 85 & $43,8 \%$ & 24 & $19,3 \%$ \\
Doesn't have & 236 & $66,5 \%$ & 27 & $73 \%$ & 109 & $56,2 \%$ & 100 & $80,6 \%$ \\
Total & 355 & & 37 & & 194 & & 124 & \\
\hline
\end{tabular}

Elaborated by the authors (2019). Source: Parameterized Report (NRCU, 28/04/2019).

Table 15 reveals that 119 EPA (33.5\%) has other management tools. It attempted to investigate whether the EPA has other management tools on the official websites to verify the adequacy of the data obtained in the parameterized report of the NRCU.

Table 16 shows the data crossing of other management tools in the EPA, according to the parameterized report of the NRCU and the search of the official websites. 
Table 16 - Number of EPA with other management instruments

\begin{tabular}{lcccccccc}
\hline $\begin{array}{l}\text { Other } \\
\text { management } \\
\text { tools }\end{array}$ & $\mathbf{N}^{\circ}$. & $\begin{array}{c}\text { Total } \\
\mathbf{\%}\end{array}$ & $\begin{array}{c}\text { Federal } \\
\left(\mathbf{n}^{\circ} . \mathbf{}\right)\end{array}$ & $\begin{array}{c}\text { federal } \\
\text { total \% }\end{array}$ & $\begin{array}{c}\text { State } \\
\left(\mathbf{n}^{\circ} . \mathbf{}\right)\end{array}$ & $\begin{array}{c}\text { state } \\
\text { total \% }\end{array}$ & $\begin{array}{c}\text { Municipal } \\
\left(\mathbf{n}^{\circ} .\right)\end{array}$ & $\begin{array}{c}\text { municipal } \\
\text { total \% }\end{array}$ \\
\hline Has & 107 & $30,1 \%$ & 15 & $40,5 \%$ & 76 & $39,2 \%$ & 16 & $12,9 \%$ \\
Doesn't have & 164 & $46,2 \%$ & 21 & $56,8 \%$ & 115 & $59,3 \%$ & 28 & $22,6 \%$ \\
Couldn't verify & 84 & $23,7 \%$ & 1 & $2,7 \%$ & 3 & $1,5 \%$ & 80 & $64,5 \%$ \\
Total & 355 & & 37 & & 194 & & 124 & \\
\hline
\end{tabular}

Elaborated by the authors (2019). Source: Parameterized Report (NRCU, 28/04/2019); official websites of NCU Management Agencies of the Government.

Table 16 reveals that 107 EPA (30.1\%) has other management tools, a number below the NRCU parameterized report (TABLE 15). Still, there was no way to reveal whether the information in the notice is overestimated, with security.

The lack of Environmental Zoning and its regulation weakens the EPA management since its normative and restrictive dimension is fundamental to controlling the environment of this management category.

Below is an analysis on the theme of infrastructure, (1) communication infrastructure (TABLE 17); (2) transportation infrastructure (TABLE 18); (3) improvements infrastructure (TABLE 19); (4) basic infrastructure ${ }^{7}$ (TABLE 20); (5) human resources (TABLE 21); (6) emergency support infrastructure (TABLE 22) in EPA according to data from the NRCU parameterized report.

\footnotetext{
7 Basic infrastructure refers to urban infrastructure or urban types of equipment - fresh water distribution network, domestic wastewater collection network, and treatment, collection, and treatment of urban solid waste, road network with rainwater channeling, electricity distribution network, and public lighting (CONAMA Resolution No. 302/2002, Art. 2, V, b). As not all EPA has an urban area, it is understood according to the NRCU, availability of freshwater, and a collection network for domestic effluents or septic tanks. There is no data on the other urban equipment in the NRCU.
} 
Table 17 - EPA communication infrastructure

\begin{tabular}{lcccccccc}
\hline $\begin{array}{l}\text { Communication } \\
\text { infrastructure }\end{array}$ & $\mathbf{N}^{\circ}$. & $\begin{array}{c}\text { Total } \\
\mathbf{\%}\end{array}$ & $\begin{array}{c}\text { Federal } \\
\left(\mathbf{n}^{\circ} .\right)\end{array}$ & $\begin{array}{c}\text { federal } \\
\text { total \% }\end{array}$ & $\begin{array}{c}\text { State } \\
\left(\mathbf{n}^{\circ} . \mathbf{}\right)\end{array}$ & $\begin{array}{c}\text { state } \\
\text { total \% }\end{array}$ & $\begin{array}{c}\text { Municipal } \\
\left(\mathbf{n}^{\circ} . \mathbf{}\right)\end{array}$ & $\begin{array}{c}\text { municipal } \\
\text { total \% }\end{array}$ \\
\hline Has & 149 & $42 \%$ & 16 & $43,2 \%$ & 80 & $41,2 \%$ & 53 & $42,7 \%$ \\
Doesn't have & 57 & $16,1 \%$ & 1 & $2,7 \%$ & 21 & $10,8 \%$ & 35 & $28,2 \%$ \\
$\begin{array}{l}\text { Doesn't have } \\
\text { information }\end{array}$ & 149 & $42 \%$ & 20 & $54 \%$ & 93 & $47,9 \%$ & 36 & $29 \%$ \\
Total & 355 & & 37 & & 194 & & 124 & \\
\hline
\end{tabular}

Elaborated by the authors (2019). Source: Parameterized Report (NRCU, 28/04/2019).

Table 18 - EPA transportation infrastructure

\begin{tabular}{|c|c|c|c|c|c|c|c|c|}
\hline $\begin{array}{l}\text { Transportation } \\
\text { infrastructure }\end{array}$ & $\mathbf{N}^{\circ}$. & $\begin{array}{l}\text { Total } \\
\%\end{array}$ & $\begin{array}{c}\text { Federal } \\
\left(n^{\circ} .\right)\end{array}$ & $\begin{array}{l}\text { federal } \\
\text { total } \%\end{array}$ & $\begin{array}{l}\text { State } \\
\left(n^{\circ} .\right)\end{array}$ & $\begin{array}{c}\text { state } \\
\text { total \% }\end{array}$ & $\begin{array}{c}\text { Municipal } \\
\left(n^{\circ} .\right)\end{array}$ & $\begin{array}{c}\text { municipal } \\
\text { total } \%\end{array}$ \\
\hline Has & 82 & $23,1 \%$ & 14 & $37,8 \%$ & 48 & $24,7 \%$ & 20 & $16,1 \%$ \\
\hline Doesn't have & 125 & $35,2 \%$ & 3 & $8,1 \%$ & 54 & $27,8 \%$ & 68 & $54,8 \%$ \\
\hline $\begin{array}{l}\text { Doesn't have } \\
\text { information }\end{array}$ & 148 & $41,7 \%$ & 20 & $54 \%$ & 92 & $47,4 \%$ & 36 & $29 \%$ \\
\hline Total & 355 & & 37 & & 194 & & 124 & \\
\hline
\end{tabular}

Elaborated by the authors (2019). Source: Parameterized Report (NRCU, 28/04/2019).

Table 19 - EPA improvements infrastructure

\begin{tabular}{|c|c|c|c|c|c|c|c|c|}
\hline $\begin{array}{l}\text { Improvement's } \\
\text { infrastructure }\end{array}$ & $\mathbf{N}^{\circ}$. & $\begin{array}{c}\text { Total } \\
\%\end{array}$ & $\begin{array}{c}\text { Federa } \\
I\left(n^{\circ} .\right)\end{array}$ & $\begin{array}{c}\text { federal } \\
\text { total } \\
\%\end{array}$ & $\begin{array}{c}\text { State } \\
\left(n^{\circ} .\right)\end{array}$ & $\begin{array}{c}\text { state total } \\
\%\end{array}$ & $\begin{array}{l}\text { Municipal } \\
\left(n^{\circ} .\right)\end{array}$ & $\begin{array}{c}\text { municipal } \\
\text { total } \\
\%\end{array}$ \\
\hline $\begin{array}{l}\text { Ordinance or } \\
\text { Portal }\end{array}$ & 12 & $3,4 \%$ & 1 & $2,7 \%$ & 7 & $3,6 \%$ & 4 & $3,2 \%$ \\
\hline Visitor Center & 33 & $9,3 \%$ & 19 & $51,3 \%$ & 6 & $3,1 \%$ & 8 & $6,4 \%$ \\
\hline Headquarters & 34 & $9,6 \%$ & 5 & $13,5 \%$ & 21 & $10,8 \%$ & 8 & $6,4 \%$ \\
\hline $\begin{array}{l}\text { Operational } \\
\text { basis }\end{array}$ & 0 & $0,0 \%$ & 0 & $0,0 \%$ & 0 & $0,0 \%$ & 0 & $0,0 \%$ \\
\hline Bathroom & 64 & $18 \%$ & 14 & $37,8 \%$ & 42 & $21,6 \%$ & 8 & $6,4 \%$ \\
\hline Lodging & 15 & $4,2 \%$ & 6 & $16,2 \%$ & 8 & $4,1 \%$ & 1 & $0,8 \%$ \\
\hline Parking lot & 21 & $5,9 \%$ & 2 & $5,4 \%$ & 10 & $5,1 \%$ & 9 & $7,3 \%$ \\
\hline Security cabin & 9 & $2,5 \%$ & 0 & $0,0 \%$ & 4 & $2,1 \%$ & 5 & $4 \%$ \\
\hline
\end{tabular}


Table 19 - Conclusion

\begin{tabular}{lcccccccc}
\hline $\begin{array}{l}\text { Improvement's } \\
\text { infrastructure }\end{array}$ & $\mathbf{N}^{\circ}$. & $\begin{array}{c}\text { Total } \\
\%\end{array}$ & $\begin{array}{c}\text { Federal } \\
\left(\mathbf{n}^{\circ} .\right)\end{array}$ & $\begin{array}{c}\text { federal } \\
\text { total \% }\end{array}$ & $\begin{array}{c}\text { State } \\
\left(\mathbf{n}^{\circ} .\right)\end{array}$ & $\begin{array}{c}\text { state total } \\
\%\end{array}$ & $\begin{array}{c}\text { Municipal } \\
\left(\mathbf{n}^{\circ} .\right)\end{array}$ & $\begin{array}{c}\text { municipal } \\
\text { total \% }\end{array}$ \\
\hline Doesn't have & 122 & $34,4 \%$ & 3 & $8,1 \%$ & 53 & $27,3 \%$ & 66 & $53,2 \%$ \\
$\begin{array}{l}\text { Doesn't have } \\
\text { information }\end{array}$ & 151 & $42,5 \%$ & 20 & $54 \%$ & 95 & $49 \%$ & 36 & $29 \%$ \\
\hline
\end{tabular}

Elaborated by the authors (2019). Source: Parameterized Report (NRCU, 28/04/2019).

Table 20 - EPA basic infrastructure

\begin{tabular}{|c|c|c|c|c|c|c|c|c|}
\hline $\begin{array}{l}\text { Basic } \\
\text { infrastructure }\end{array}$ & $\mathbf{N}^{\circ}$ & $\begin{array}{c}\text { Total } \\
\%\end{array}$ & $\begin{array}{l}\text { Federal } \\
\left(n^{\circ} .\right)\end{array}$ & $\begin{array}{l}\text { federal } \\
\text { total \% }\end{array}$ & $\begin{array}{l}\text { State } \\
\left(n^{\circ} .\right)\end{array}$ & $\begin{array}{c}\text { state } \\
\text { total \% }\end{array}$ & $\begin{array}{l}\text { Municipal } \\
\left(n^{\circ} .\right)\end{array}$ & $\begin{array}{c}\text { municipal } \\
\text { total } \%\end{array}$ \\
\hline Electricity & 137 & $38,6 \%$ & 16 & $43,2 \%$ & 71 & $36,6 \%$ & 50 & $40,3 \%$ \\
\hline Freshwater & 95 & $26,8 \%$ & 13 & $35,1 \%$ & 54 & $27,8 \%$ & 28 & $22,6 \%$ \\
\hline $\begin{array}{l}\text { Sewer collection } \\
\text { network }\end{array}$ & 40 & $11,3 \%$ & 6 & $16,2 \%$ & 10 & $5,1 \%$ & 24 & $19,3 \%$ \\
\hline Septic tank & 55 & $15,5 \%$ & 8 & $21,6 \%$ & 30 & $15,5 \%$ & 17 & $13,7 \%$ \\
\hline Doesn't have & 48 & $13,5 \%$ & 1 & $2,7 \%$ & 22 & $11,3 \%$ & 25 & $20,2 \%$ \\
\hline $\begin{array}{l}\text { Doesn't have } \\
\text { information }\end{array}$ & 155 & $43,7 \%$ & 20 & $54 \%$ & 98 & $50,5 \%$ & 37 & $29,8 \%$ \\
\hline
\end{tabular}

Elaborated by the authors (2019). Source: Parameterized Report (NRCU, 28/04/2019).

Table 21 - EPA human resources

\begin{tabular}{lcccccccc}
\hline $\begin{array}{l}\text { Human } \\
\text { resources }\end{array}$ & $\mathbf{N}^{\circ}$. & Total \% & $\begin{array}{c}\text { Federal } \\
\left(\mathbf{n}^{\circ} .\right)\end{array}$ & $\begin{array}{c}\text { federal } \\
\text { total \% }\end{array}$ & $\begin{array}{c}\text { State } \\
\left(\mathbf{n}^{\circ} . \mathbf{}\right)\end{array}$ & $\begin{array}{c}\text { state } \\
\text { total \% }\end{array}$ & $\begin{array}{c}\text { Municipal } \\
\left(\mathbf{n}^{\circ} .\right)\end{array}$ & $\begin{array}{c}\text { municipa } \\
\text { I total \% }\end{array}$ \\
\hline 1 & 51 & $14,4 \%$ & 3 & $8,1 \%$ & 35 & $18 \%$ & 13 & $10,5 \%$ \\
2 & 31 & $8,7 \%$ & 3 & $8,1 \%$ & 12 & $6,2 \%$ & 16 & $12,9 \%$ \\
3 & 11 & $3,1 \%$ & 1 & $2,7 \%$ & 4 & $2,1 \%$ & 6 & $4,8 \%$ \\
4 & 16 & $4,5 \%$ & 5 & $13,5 \%$ & 9 & $4,6 \%$ & 2 & $1,6 \%$ \\
5 & 0 & $0,0 \%$ & 0 & $0,0 \%$ & 0 & $0,0 \%$ & 0 & $0,0 \%$ \\
6 & 8 & $2,2 \%$ & 2 & $5,4 \%$ & 1 & $0,5 \%$ & 5 & $4 \%$ \\
7 & 4 & $1,1 \%$ & 1 & $2,7 \%$ & 2 & $1 \%$ & 1 & $0,8 \%$ \\
8 & 1 & $0,3 \%$ & 0 & $0,0 \%$ & 1 & $0,5 \%$ & 0 & $0,0 \%$ \\
9 & 1 & $0,3 \%$ & 0 & $0,0 \%$ & 0 & $0,0 \%$ & 1 & $0,8 \%$ \\
\hline
\end{tabular}


Table 21 - Conclusion

\begin{tabular}{|c|c|c|c|c|c|c|c|c|}
\hline $\begin{array}{l}\text { Human } \\
\text { resources }\end{array}$ & $\mathbf{N}^{\circ}$ & Total \% & $\begin{array}{c}\text { Federal } \\
\left(n^{\circ} .\right)\end{array}$ & $\begin{array}{l}\text { federal } \\
\text { total } \%\end{array}$ & $\begin{array}{c}\text { State } \\
\left(n^{\circ} .\right)\end{array}$ & $\begin{array}{c}\text { state } \\
\text { total \% }\end{array}$ & $\begin{array}{c}\text { Municipal } \\
\left(n^{\circ} .\right)\end{array}$ & $\begin{array}{c}\text { municipal } \\
\text { total } \%\end{array}$ \\
\hline 10 & 3 & $0,8 \%$ & 0 & $0,0 \%$ & 2 & $1 \%$ & 1 & $0,8 \%$ \\
\hline+10 & 12 & $3,4 \%$ & 2 & $5,4 \%$ & 2 & $1 \%$ & 8 & $6,4 \%$ \\
\hline $\begin{array}{l}\text { Doesn't } \\
\text { have }\end{array}$ & 5 & $1,4 \%$ & 0 & $0,0 \%$ & 0 & $0,0 \%$ & 5 & $4 \%$ \\
\hline $\begin{array}{l}\text { Doesn't } \\
\text { have } \\
\text { information }\end{array}$ & 212 & $59,7 \%$ & 20 & $54 \%$ & 126 & $64,9 \%$ & 66 & $53,2 \%$ \\
\hline Total & 355 & & 37 & & 194 & & 124 & \\
\hline
\end{tabular}

Elaborated by the authors (2019). Source: Parameterized Report (NRCU, 28/04/2019).

Table 22 - EPA emergency support infrastructure

\begin{tabular}{|c|c|c|c|c|c|c|c|c|}
\hline $\begin{array}{l}\text { Emergency } \\
\text { support } \\
\text { infrastructure }\end{array}$ & $\mathbf{N}^{\circ}$. & $\begin{array}{c}\text { Total } \\
\%\end{array}$ & $\begin{array}{c}\text { Federal } \\
\left(n^{\circ} .\right)\end{array}$ & $\begin{array}{c}\text { federal } \\
\text { total } \\
\%\end{array}$ & $\begin{array}{c}\text { State } \\
\left(n^{\circ} .\right)\end{array}$ & $\begin{array}{c}\text { state total } \\
\%\end{array}$ & $\begin{array}{l}\text { Municipal } \\
\left(n^{\circ} .\right)\end{array}$ & $\begin{array}{c}\text { municipal } \\
\text { total } \\
\%\end{array}$ \\
\hline Has & 6 & $1,7 \%$ & 0 & $0,0 \%$ & 5 & $2,6 \%$ & 1 & $0,8 \%$ \\
\hline Doesn't have & 2 & $0,5 \%$ & 1 & $2,7 \%$ & 1 & $0,5 \%$ & 0 & $0,0 \%$ \\
\hline $\begin{array}{l}\text { Doesn't have } \\
\text { information }\end{array}$ & 347 & $97,7 \%$ & 36 & $97,3 \%$ & 188 & $96,9 \%$ & 123 & $99,2 \%$ \\
\hline Total & 355 & & 37 & & 194 & & 124 & \\
\hline
\end{tabular}

Elaborated by the authors (2019). Source: Parameterized Report (NRCU, 28/04/2019).

Regarding the existence of Infrastructure in EPA, It evidenced that: a) 147 EPA (41.4\%) do not have any information about the existence of infrastructure (communication; transportation; improvements, and essential); b) 31 EPA (8.7\%) do not have any infrastructure (communication; transportation; improvements, and essential); c) none EPA has all the infrastructures (communication; transportation; improvements, and primary).

In addition, there are: a) less than half of the EPA has Communication Infrastructure (42\%); b) only 82 EPA (23.1\%) has Transport Infrastructure; c) 122 EPA (34.4\%) do not have any improvement; d) less than $40 \%$ of EPA has an 
electricity supply, sanitary effluent treatment, and freshwater distribution; e) 212 EPA (59.7\%) do not have information on whether or not they have human resources; f) only 138 EPA (38.5\%) has human resources; f) 347 EPA (97.7\%) do not have information about the existence of an emergency support infrastructure, only six EPA say it has the structure, and two say they do not; g) the Register does not inform whether human resources, communication, transportation, primary and emergency infrastructure are exclusive to EPA or are shared (TABLE 17; 18; 19; 20; $21 ; 22)$.

There is no framework in the NRCU regarding the EPA financial resources, so he did not compose this analysis. The deficiency or lack of resources (human, logistical, economic, and infrastructural) makes NCU management difficult or impossible.

The scenery described above reveals that it is necessary to implant most EPA, but ones do not implant them properly. It was not possible to assess the sufficiency and continuity of resources.

As for land ownership, public and private areas can make up EPA. It is necessary to identify them to guarantee management and control as it is the responsibility of the public authorities to control public areas and police private ones, including the visitation and scientific research.

Table 23 shows the analysis of the land ownership data according to the parameterized report of the NRCU. 
Table 23 - EPA land ownership

\begin{tabular}{|c|c|c|c|c|c|c|c|c|}
\hline $\begin{array}{l}\text { Land } \\
\text { ownership }\end{array}$ & $\mathbf{N}^{\circ}$. & $\begin{array}{c}\text { Total } \\
\%\end{array}$ & $\begin{array}{c}\text { Federal } \\
\left(n^{\circ} .\right)\end{array}$ & $\begin{array}{l}\text { federal } \\
\text { total \% }\end{array}$ & $\begin{array}{c}\text { State } \\
\left(n^{\circ} .\right)\end{array}$ & $\begin{array}{l}\text { of state } \\
\text { total \% }\end{array}$ & $\begin{array}{l}\text { Municipal } \\
\left(n^{\circ} .\right)\end{array}$ & $\begin{array}{c}\text { municipa } \\
\text { I total \% }\end{array}$ \\
\hline Public only & 9 & $2,5 \%$ & 2 & $5,4 \%$ & 6 & $3,1 \%$ & 1 & $0,8 \%$ \\
\hline Private only & 17 & $4,8 \%$ & 2 & $5,4 \%$ & 2 & $1 \%$ & 13 & $10,5 \%$ \\
\hline $\begin{array}{l}\text { Public, and } \\
\text { private }\end{array}$ & 16 & $4,5 \%$ & 1 & $2,7 \%$ & 5 & $2,6 \%$ & 10 & $8,1 \%$ \\
\hline $\begin{array}{l}\text { Doesn't have } \\
\text { information }\end{array}$ & 313 & $88,2 \%$ & 32 & $86,5 \%$ & 181 & $93,3 \%$ & 100 & $80,6 \%$ \\
\hline Total & 355 & & 37 & & 194 & & 124 & \\
\hline
\end{tabular}

Elaborated by the authors (2019). Source: Parameterized Report (NRCU, 28/04/2019).

Table 23 reveals that 313 APAs (approximately 88.2\%) do not have information regarding the ownership of their lands, which negatively affects their control and enforcement. Table 24 shows the analysis of access to visitors data, and Table 25 for its control, according to the parameterized report from the NRCU. According to the tables, 258 EPA (72.6\%) do not have information on the existence of visitation, and, among the 82 APAs (23.1\%) that has visitation, only nine (2.5\%) has it control, which impairs the power, and enforcement of the activity.

Table 24 - EPA access to visitors

\begin{tabular}{|c|c|c|c|c|c|c|c|c|}
\hline $\begin{array}{l}\text { Access to } \\
\text { visitors }\end{array}$ & $\mathbf{N}^{\circ}$. & $\begin{array}{c}\text { Total } \\
\%\end{array}$ & $\begin{array}{c}\text { Federal } \\
\left(n^{\circ} .\right)\end{array}$ & $\begin{array}{l}\text { federal } \\
\text { total } \%\end{array}$ & $\begin{array}{c}\text { State } \\
\left(n^{\circ} .\right)\end{array}$ & $\begin{array}{c}\text { state total } \\
\%\end{array}$ & $\begin{array}{c}\text { Municipal } \\
\left(n^{\circ} .\right)\end{array}$ & $\begin{array}{c}\text { municipal } \\
\text { total } \%\end{array}$ \\
\hline Has & 82 & $23,1 \%$ & 6 & $16,2 \%$ & 37 & $19,1 \%$ & 39 & $31,4 \%$ \\
\hline $\begin{array}{l}\text { Doesn't } \\
\text { have }\end{array}$ & 15 & $4,2 \%$ & 2 & $5,4 \%$ & 0 & $0,0 \%$ & 13 & $10,5 \%$ \\
\hline $\begin{array}{l}\text { Doesn't } \\
\text { have } \\
\text { informati } \\
\text { on }\end{array}$ & 258 & $72,7 \%$ & 29 & $78,4 \%$ & 157 & $80,9 \%$ & 72 & $58,1 \%$ \\
\hline Total & 355 & & 37 & & 194 & & 124 & \\
\hline
\end{tabular}

Elaborated by the authors (2019). Source: Parameterized Report (NRCU, 28/04/2019). 
Table 25 - Visitation control

\begin{tabular}{|c|c|c|c|c|c|c|c|c|}
\hline $\begin{array}{l}\text { Visitation } \\
\text { control }\end{array}$ & $\mathbf{N}^{\circ}$ & $\begin{array}{c}\text { Total } \\
\%\end{array}$ & $\begin{array}{c}\text { Federal } \\
\left(n^{\circ} .\right)\end{array}$ & $\begin{array}{l}\text { federal } \\
\text { total } \%\end{array}$ & $\begin{array}{c}\text { State } \\
\left(n^{\circ} .\right)\end{array}$ & $\begin{array}{c}\text { state total } \\
\%\end{array}$ & $\begin{array}{l}\text { Municipal } \\
\quad\left(n^{\circ} .\right)\end{array}$ & $\begin{array}{c}\text { municipal } \\
\text { total } \%\end{array}$ \\
\hline Has & 9 & $2,5 \%$ & 1 & $2,7 \%$ & 2 & $1 \%$ & 6 & $4,8 \%$ \\
\hline Doesn't have & 49 & $13,8 \%$ & 3 & $8,1 \%$ & 27 & $13,9 \%$ & 19 & $15,3 \%$ \\
\hline $\begin{array}{l}\text { Doesn't have } \\
\text { information }\end{array}$ & 282 & $79,4 \%$ & 31 & $83,8 \%$ & 165 & $85 \%$ & 86 & $69,3 \%$ \\
\hline $\begin{array}{l}\text { Doesn't have } \\
\text { visitation }\end{array}$ & 15 & $4,2 \%$ & 2 & $5,4 \%$ & 0 & $0,0 \%$ & 13 & $10,5 \%$ \\
\hline Total & 355 & & 37 & & 194 & & 124 & \\
\hline
\end{tabular}

Elaborated by the authors (2019). Source: Parameterized Report (NRCU, 28/04/2019).

There is no item on research control in the NRCU parameterized report, despite being a legal requirement.

Environmental education is an obligation for $\mathrm{NCU}$, according to $\mathrm{NSNCU}^{8}$, in addition to be a Principle of the National Environmental Education Policy. The NRCU separates ecological education activities into: "Environmental education activities linked to formal teaching at NCU"; "Interpretive/educational activities offered to visitors"; "Environmental education campaign in the surroundings"; "Environmental education campaign for natural resources users"; "Other environmental education programs." We chose to identify EPA with environmental education activities or not simply. Table 26 shows the analysis of data on environmental education activities from the parameterized report of the NRCU.

Table 26 - EPA environmental education activities

\begin{tabular}{lcccccccc}
\hline $\begin{array}{l}\text { Environmental } \\
\text { education } \\
\text { activities }\end{array}$ & $\mathbf{N}^{\circ}$. & $\begin{array}{c}\text { Total } \\
\mathbf{\%}\end{array}$ & $\begin{array}{c}\text { Federal } \\
\left(\mathbf{n}^{\circ} .\right)\end{array}$ & $\begin{array}{c}\text { federal } \\
\text { total } \%\end{array}$ & $\begin{array}{c}\text { State } \\
\left(\mathbf{n}^{\circ} .\right)\end{array}$ & $\begin{array}{c}\text { state total } \\
\mathbf{\%}\end{array}$ & $\begin{array}{c}\text { Municipal } \\
\left(\mathbf{n}^{\circ} .\right)\end{array}$ & $\begin{array}{c}\text { municipal } \\
\text { total \% }\end{array}$ \\
\hline Has & 62 & $17,5 \%$ & 8 & $21,6 \%$ & 18 & $9,3 \%$ & 36 & $29 \%$ \\
\hline
\end{tabular}

${ }^{8}$ Art. $5^{\circ}$, III da Federal Law no. 9.985/2000. 
Table 26 - Conclusion

\begin{tabular}{lcccccccc}
\hline $\begin{array}{l}\text { Environmental } \\
\text { education } \\
\text { activities }\end{array}$ & $\mathbf{N}^{\circ}$. & $\begin{array}{c}\text { Total } \\
\%\end{array}$ & $\begin{array}{c}\text { Federal } \\
\left(\mathbf{n}^{\circ} . \mathbf{)}\right.\end{array}$ & $\begin{array}{c}\text { federal } \\
\text { total \% }\end{array}$ & $\begin{array}{c}\text { State } \\
\left(\mathbf{n}^{\circ} .\right)\end{array}$ & $\begin{array}{c}\text { state } \\
\text { total } \%\end{array}$ & $\begin{array}{c}\text { Municipal } \\
\left(\mathbf{n}^{\circ} .\right)\end{array}$ & $\begin{array}{c}\text { municipal } \\
\text { total \% }\end{array}$ \\
\hline $\begin{array}{l}\text { Doesn't have } \\
\text { Doesn't have }\end{array}$ & 211 & $23,1 \%$ & 7 & $18,9 \%$ & 45 & $23,2 \%$ & 30 & $24,2 \%$ \\
information & $59,4 \%$ & 22 & $59,5 \%$ & 131 & $67,5 \%$ & 58 & $46,8 \%$ \\
Total & 355 & & 37 & & 194 & & 124 & \\
\hline
\end{tabular}

Elaborated by the authors (2019). Source: Parameterized Report (NRCU, 28/04/2019).

Table 26 reveals that approximately 62 EPA (17.5\%) has information about environmental education activities, such data being absent in 211 EPA (59\%). Environmental education is essential to raise awareness among social actors, especially regarding the EPA's mission, values, objectives, scope, and restrictions. However, in addition to the high number of EPA that do not carry out environmental education, it was impossible to verify this activity's adequacy, sufficiency, and continuities with the available data.

It was not possible to draw a comparison between the information in the NRCU parameterized report. Due to the online data gap, its infrastructure is in the official websites, human resources, emergency support, land ownership, access to visitation, visitation control, and environmental education activities.

Table 27 shows the EPA conformity NSNCU determinations analysis and its regulatory decree, according to the data of the parameterized report of the NRCU. 
Table 27 - Compliance of EPA with NSNCU, and its Decree no. 4.340 / $2002^{9}$

\begin{tabular}{|c|c|c|c|c|c|c|c|c|}
\hline Compliance & $\mathbf{N}^{\circ}$ & $\begin{array}{c}\text { Total } \\
\%\end{array}$ & $\begin{array}{c}\text { Federal } \\
\left(n^{\circ} .\right)\end{array}$ & $\begin{array}{l}\text { federal } \\
\text { total } \%\end{array}$ & $\begin{array}{l}\text { State } \\
\left(n^{\circ} .\right)\end{array}$ & $\begin{array}{c}\text { state } \\
\text { total } \\
\%\end{array}$ & $\begin{array}{l}\text { Municipal } \\
\left(n^{\circ} .\right)\end{array}$ & $\begin{array}{c}\text { municipal } \\
\text { total } \%\end{array}$ \\
\hline $\begin{array}{l}\text { Has a Management } \\
\text { Plan }\end{array}$ & 85 & $23,9 \%$ & 16 & $43,2 \%$ & 52 & $26,8 \%$ & 17 & $13,7 \%$ \\
\hline $\begin{array}{l}\text { Management Plan } \\
\text { with the ordinance }\end{array}$ & 34 & $9,6 \%$ & 4 & $10,8 \%$ & 22 & $11,3 \%$ & 8 & $6,4 \%$ \\
\hline $\begin{array}{l}\text { Management Plan at } \\
\text { the appropriate } \\
\text { phase }\end{array}$ & 25 & $7 \%$ & 14 & $37,8 \%$ & 8 & $4,1 \%$ & 3 & $2,4 \%$ \\
\hline $\begin{array}{l}\text { Management Plan } \\
\text { with the ordinance, } \\
\text { and at the } \\
\text { appropriate phase }\end{array}$ & 7 & $2 \%$ & 1 & $2,7 \%$ & 3 & $1,5 \%$ & 3 & $2,4 \%$ \\
\hline $\begin{array}{l}\text { Has a Management } \\
\text { Council }\end{array}$ & 175 & $49,3 \%$ & 27 & $73 \%$ & 118 & $60,8 \%$ & 30 & $24,2 \%$ \\
\hline $\begin{array}{l}\text { Management Council } \\
\text { with Internal } \\
\text { Regiment }\end{array}$ & 99 & $27,9 \%$ & 0 & $0,0 \%$ & 87 & $44,8 \%$ & 12 & $9,7 \%$ \\
\hline $\begin{array}{l}\text { Has control over your } \\
\text { visitation or don't } \\
\text { have visitation }\end{array}$ & 24 & $6,8 \%$ & 3 & $8,1 \%$ & 2 & $1,0 \%$ & 19 & $15,3 \%$ \\
\hline $\begin{array}{l}\text { Management Plan } \\
\text { with an ordinance, } \\
\text { and at an appropriate } \\
\text { phase, Management } \\
\text { Council with the } \\
\text { internal regiment, } \\
\text { and control of } \\
\text { visitation or without } \\
\text { visitation }\end{array}$ & 1 & $0,3 \%$ & 0 & $0,0 \%$ & 0 & $0,0 \%$ & 1 & $0,8 \%$ \\
\hline
\end{tabular}

Elaborated by the authors (2019). Source: Parameterized Report (NRCU, 28/04/2019); official websites of NCU Management Agencies of the Government.

Table 27 reveals that:

i. only seven EPA has a Management Plan regulated, and in an adequate phase, that is, reviewed;

${ }^{9}$ The blank information in the NRCU, and the non-existence of it in other sources were not computed. 
ii. 175 EPA (40.3\%) has a Management Council in place, but only 99 of them (27.9\%) have Internal Regiment, that is, the document that regulates their performance;

iii. only 24 EPA (6.8\%) have control over your visitation or do not have visitation. The public or private visit and research control are not informed.

iv. 83 EPA (23.4\%) registers in CNU certification in about two years, according to Management Council;

v. EPA has incomplete information ${ }^{10}$ in disagreement ${ }^{11}$ with the official websites or NRCU blank reports, which means it does not have any knowledge;

vi. none EPA is in full compliance with NSNCU ${ }^{12}$, although all of them declare to be.

\section{DISCUSSION}

The public authorities' administrative spheres (federal, state, and municipal) NRCU (2019) data parameterized EPA report analysis reveals two worrying situations:

i. EPA proper implantation and management is necessary; that is, none of them has more pop resources, and their management is not really in compliance with the NSNCU, and its regulatory decree, which turns into different levels of paper EPA, according to the data analyzed;

\footnotetext{
10 Incomplete or erroneous information.

11 Information in disagreement with the official websites.

12 Management Plan with an ordinance, and at an appropriate phase, Management Council with the internal regiment, and control of visitation or without visitation. NRCU registration is mandatory, but its update is not mandatory in SNUC, Decree $n^{\circ} .4 .340$ / 2002, and CONAMA Resolution no. 371/2006 (BRAZIL, 2006). Despite the Transparency Law guaranteeing it.
} 
ii. Most of the EPA have all or part of their information in a blank, and it is common to be not proper, inadequate, or outdated information in the NRCU.

According to the previous information, the EPA implementation and management were not adequate. The gap, deficiency, and inadequacy of the available data on EPA are so significant that it is impossible to verify whether the management category and its implanted protected sites are correctly functioning. Moreover, the registration absence in the NRCU is inadequate, defective filling, and outdated information are not in accord with the NSNCU's determination.

In this context, Bensusan (2006) states that there are countless paper EPA due to the low investment of the Government in the NCU of this management category. Still, Bensusan (2006), Pureza, Pellin, and Padua (2014), and Souza (2014), warn that there is a government strategy to create protected sites in the EPA management category without resources for implantation or for their daily operation (paper EPA), which corroborates the data found in this article.

An illustrative example of this alert is about the first EPA created in Brazil. One built the Federal APA for the Região da Serra de Petrópolisin 1982, one year five months after the Law for Ecological Stations and Environmental Protection Areas. However, legality only started eight years later, and the cartographic limits were delimited ten years later. It created the Deliberative Management Council in 2001, and the Management Plan was regulated only in 2005. In other words, the social participation space and the central EPA control and ordering rules only past 23 years after its creation (ICMBio, s.d, APA da Região Serrana de Petrópolis).

Two other common cases found were:

(i) When the Government wants to create a Park or other NCU of the Integral Protection Group but does not have resources for operation, mainly for land expropriation, or even does not want to promote expropriation. With this, it creates a strict EPA without resources, which leads to creating an EPA focused on "environmental preservation," which goes against the primary objective of the 
management category. In addition to configuring the site as subject to expropriation even though it is not an NCU of the Integral Protection Group ${ }^{13}$, factors that promote conflicts., and,

(ii) The Government aims the NCU creation to increase statistics on the protected sites and coverage number, even without proper resources and management implantation, concerning their interests in protecting the environment. It raises permissive EPA (without a Management Plan and Environmental Zoning) or just aimed at extractive, use, and human occupation, even if sustainable. Such a strategy creates a problem: the absence of instruments to protect biodiversity, to control the process of occupying space, and to use and access natural resources in a sustainable manner, which is the general objective of an EPA. Sites with these characteristics should be classified as Sustainable Development Areas and not as EPA due to the absence of the primary objective of an NCU and opposition to the general objective of the management category.

This problem of the creation of EPA stringent and focused on "environmental preservation," permissive or focused on extractive, is described by Maretti (2008) and Pureza, Pellin, and Padua (2014).

In the same sense, Souza (2014) reports that this scenario is common to all management categories of NCU of the NSNCU. The author conducted an overflight

\footnotetext{
${ }^{13}$ There is a tendency to believe that private land in an EPA cannot be expropriated for preservation purposes. The CONAMA Resolution n. 10/88 (BRAZIL, 1988), now revoked, only gives a margin to evaluate case by case, with no obligation. However, it does not exempt cases where there is a need to expropriate private land.

Direct expropriation: entails the possession of the property by the State. In it, compensatory interest is due from the early imposition in possession. Eg., the creation of a National Park.

Indirect expropriation: it entails that there are administrative restrictions of such an amount that make any economic use of the land unfeasible, by the owners, resulting in an economic emptying or depreciation of the economic value of the property.

In it, compensatory interest is due according to Precedent No. 618 of the Supreme Court of Justice (STJ), "In the case of expropriation, directly or indirectly, the rate of compensatory interest is $12 \%$ (twelve percent) per year". In this case, from the date of publication of the act causing administrative seizure to actual payment. Eg., private property in an EPA Wildlife Preservation Zone with direct use of land, and natural resources should be expropriated.
} 
search $^{14}$ in the parameterized reports of the protected sites (federal, state, and municipal) of all management categories. From that, she noted that most information about NCU is incomplete, that is, blank. She also realized that there is almost no information about the NCU land property, its number of employees, environmental education programs, and projects if the NCU is open to the visitors, among other important information.

She also noted that, when registrations on NRCU are in place, most of them have worrying information such as: (1) the number of employees in the NCU is usually incipient to promote adequate management. Most protected sites do not have land title regularization, even among those created for almost thirty years (SOUZA, 2014).

Still, Vallejo (2017) and Souza (2014) report that the absence or lack of resources of Management Plans, and Environmental Zoning, is not a specific problem in the EPA management category, but rather a governmental strategy of self-promotion that meets the public policies of NCU. According to the authors, this occurs in all categories of NCU management in Brazil. According to the EEA (2012) and Hockings, Stolton, and Dudley (2004), something also occurs in strictly protected areas in Europe and worldwide.

Regarding corroborate Souza's observation (2014), and reinforce the results found in this research for EPA, It also conducted an overflight search over the parameterized reports of the NCU (federal, state, and municipal) of all NSNCU management categories. The NRCU blank information became evident in overflight. The lack of a Management Plan, management instruments, management council, manager, resources, land property information, borderline limits, visit access control, and environmental education actions are not unique problems EPA management category. They exist, to a greater or lesser degree, in all NSNCU management categories. In such a way, it did not implant the protected sites of all

\footnotetext{
${ }^{14}$ An overflight search would be to investigate the data contained in the parameterized reports without accounting, that is, without promoting an analysis.
} 
management categories properly. The gap, deficiency, and inadequacy of the available data are so significant that it is impossible to verify that the NSNCU was implemented.

Regarding this deficiency of the NRCU as a tool to support management, Souza (2014) believes that the NRCU does not fulfill the function it proposes. The author considers the Register provides, even if in a wrong way, an overview of the Brazilian reality, that is, that the NSNCU needs to be implemented appropriately.

This research believes in Silva, Vieira, and Veras's (2014) statement, which mentions a considerable gap between the act of creation, and the actual implementation of NCU in Brazil, as stated by Souza (2014). However, it was not possible to determine with the available information the degree of implementation of the EPA or NSNCU.

Concerning the NCU adherence to the NRCU, in 2006, CONAMA enacted CONAMA Resolution No. 371/2006, which "establishes guidelines for environmental agencies for the calculation, collection, application, approval, and control of resource expenditures arising from compensation environmental." In this legal regulation, the MMA established that the resources coming from environmental compensation would be destined exclusively to NCU recognized by NRCU as belonging to the NSNCU.

On the other hand, Bensusan (2006) considers the NRCU adhesion and the filling of the registrations appropriately did not occur at the time, something also evidenced by this work until 2019. The information gap continued in all management categories, observing non-registered EPA and the old management category certification high number. As a result, it was decided to challenge the managers' decision to research to collect data. There is no way to evaluate the efficiency of the management of the protected sites. The NSNCU, consequently, to know if the NCU, individually or at the System level, is effective in environmental protection. 
For Bensusan (2006), the deficiency in the NRCU data can only be remedied with: (i) punishment for the NCU Management Agency of the Government that do not register or complete the NCU Registries under their responsibility; (ii) increa sed research in the NCU; and, (iii) valuing the traditional knowledge of local communities.

In order to solve the problem mentioned before, it was revealed that even though the NRCU grafted adequate information, it is not enough to achieve the aim proposed. A must analyze elaboration, evaluations, and compositions of indexes concerning the creation, implantation, and management of NCU; consequently, the implementation is needed.

The NRCU platform lacks a more intuitive interface, that is, one that directs the manager to fill in the information required for NCU, which leads to a deficit of information. The Register also lacks a series of possibilities for data insertions necessary for the certification of an NCU under the Law, that is, accurate verification that the protected site complies with NSNCU. With that, it becomes necessary to update the NRCU so that it can fulfill its objectives. Still, it is necessary to develop a methodology for assessing the degree of implementation of EPA, and other management categories, according to the specificity of each one, in addition to compliance with NSNCU.

\section{CONCLUSION}

From this work, it was shown that all EPA is not in compliance with NSNCU. The EPA's NRCU parameterized reports (federal, state, and municipal) analysis reveals a considerable deficiency of information (blank, deficient, inadequate, or outdated) on the creation, implantation, and management of EPA at NRCU. The lack of information found was so great that it made it impossible analysis implement the APA management category and its protected sites. However, it was possible to 
show that all EPA are paper-protected areas at some level; they were not implanted and managed correctly.

The overflight area research conducted the NRCU baseline, NSNCU, and NCU management categories protected are, such as federal, state, and municipal. It brings the facts mentioned before. In other words, they are not EPA management category owners. All NCU management categories in Brazil have the same results. Thus, the NSNCU presents implantation and management problems, but it was not possible from the information available to define the degree of this problem.

Still, this work showed that the NRCU needs a revision to make the platform more intuitive to the managers and allow the insertion of information necessary for the analysis of the creation, implantation, and management of NCU that today are not available by the Register. Even if the NRCU had adequate information in its current model, it would not be possible to adequately assess the creation, implantation, and implementation of EPA or other management categories.

In addition, actions to promote or strengthen the creation, implantation, and management of NCU are needed when several conflicts and uncertainties regarding public environmental policies hover over the country. Thus, it becomes necessary to assess the degree of implementation of the NSNCU so that, from there, sufficient and continuous resources (financial, infrastructure, human, labor, and logistics) are implanted or adapted, in addition to programs NCU management projects, and actions.

The need to develop a methodology for assessing the degree of EPA implementation (entire creation, deployment, and management) was also identified, as well as the other management categories, according to the specificity of each one, which goes beyond NSNCU compliance, to subsidize the decision making of NCU managers.

Regarding the change in the perception of the structures of power and authority exercised in managing space and natural resources, we must pay attention to the authoritarian escalation in Brazil. The country has been 
experiencing conflicts, and uncertainties regarding environmental public policies in the last five years, especially about NCU, due to the advance of specific private interests in the community and the environmental good that has checked the country's historic environmental achievements.

With the new federal government cycle, which began in 2019, a series of actions or interests were intensified to make it more flexible, fragile, freeze, and even dismantle the performance of the environmental portfolio in the country. In this context, Brazil's structures of power and authority had a setback regarding the perception of the environmental issue, which currently falls short of a conservative model, perhaps, of contemporary adaptive management. Such a posture negatively impacts, directly and indirectly, the value and objectives of environmental protection, which undermines the creation, implantation of management of Protected Sites in the country.

In the current political, economic, and social scenario in which Brazil is found, it is not safe to question public policies musts, including the National System of Protected Areas, at this moment, given the attempt by government agents with interests to make them more flexible or dismantled. Thus, a more appropriate strategy for the current moment is signing official and unofficial agreements, with the Public Ministry aware, with the social actors, mainly the local and traditional communities that live in or around Protected Areas. In addition to local, regional, national, and international environmental activism for the defense and promotion of public environmental policies.

\section{ACKNOWLEDGMENT}

Faperj and Capes acknowledgment is the financial support of this research. 


\section{REFERENCES}

Artaza-barrios, O. H.; Schiavetti, A. Análise da efetividade do manejo de duas áreas de proteção ambiental do Litoral Sul da Bahia. Revista de Gestão Costeira Integrada-Journal of Integrated Coastal Zone Management, 7 (2), 117-128, 2007. doi: 10.5894/rgci13.

Bensusan, N. Conservação da biodiversidade em áreas protegidas. Rio de Janeiro: FGV Editora, 1. ed., 2006.

BRASIL. Decreto Federal n 4.340 de 2002. Regulamenta artigos da Lei no 9.985, de 18 de julho de 2000, que dispõe sobre o Sistema Nacional de Unidades de Conservação da Natureza NSNCU, e dá outras providências. Brasília: DOU de 23/08/2002.

BRASIL. Lei Federal no 9.985, de 18 de julho de 2000. Regulamenta o Art. 225', par. $1^{\circ}$, incisos I, II, III e VII da Constituição Federal, institui o Sistema Nacional de Unidades de Conservação da Natureza e dá outras providências. Brasília: DOU de 19/07/2000.

NRCU - Cadastro Nacional de Unidades de Conservação. Cadastro Nacional de Unidades de Conservação. s.d. Disponível em: <www.mma.gov.br/areas-protegidas/cadastro-nacional-deucs>. Acesso em: abr. 2016.

NRCU - Cadastro Nacional de Unidades de Conservação. Relatório Parametrizado de Unidade (s) de Conservação. 2019. Disponível em:

<sistemas.mma.gov.br/NRCU/index.php?ido=relatorioparametrizado.exibeFormularioPortal>. Acesso em: abr. 2019.

NRCU - Cadastro Nacional de Unidades de Conservação. Relatório de Dados Consolidados. 2019. Disponível em: <www.mma.gov.br/areas-protegidas/cadastro-nacional-de-ucs/dadosconsolidados.html>. Acesso em: jan. 2019.

CONAMA - Conselho Nacional do Meio Ambiente. Resolução CONAMA n 371, de 06 de abril de 2006. Estabelece diretrizes aos órgãos ambientais para o cálculo, cobrança, aplicação, aprovação e controle de gastos de recursos advindos de compensação ambiental, conforme a Lei no 9.985, de 18 de julho de 2000, que institui o Sistema Nacional de Unidades de Conservação da Natureza-NSNCU e dá outras providências. Brasília: DOU de 06/042006.

CONAMA - Conselho Nacional do Meio Ambiente. Resolução CONAMA n 10, de 14 de dezembro de 1988. Dispõe sobre a regulamentação das Áreas de Proteção Ambiental. Brasília: DOU de 14/12/1988.

EEA - EUROPEAN ENVIRONMENT AGENCY. Protected Areas in Europe - an overview. Copenhagen: EEA, 2012.

HOCKINGS, M.; STOLTON, S.; DUDLEY, N. Management effectiveness: assessing the management of protected areas? Journal of Environmental Policy \& Planning, 6 (2), 157-174, 2004. 
ICMBio - Instituto Chico Mendes de Conservação da Biodiversidade; WWF-Brasil - World Wide Fund for Nature from Brazil. Efetividade de Gestão das unidades de conservação federais: Avaliação comparada das aplicações do método Rappam nas unidades de conservação federais, nos ciclos 2005-06 e 2010. Brasília: ICMBio, 2012.

Maretti, C. C. Category VI. In: Dudley, N.; Stolton, S. (ed.). Defining Protected Areas: An International Conference in Almeria. Spain: International Union for Conservation of Nature, and Natural Resources (IUCN). Cap. 4.7, 2008.

MMA - Ministério do Meio Ambiente. Cadastro Nacional de UCs. Disponível em: <www.mma.gov.br/informma/itemlist/category/130-cadastro-nacional-de-uc-s>. Acesso em: jun. 2016.

Mulongoy, K. J.; Chape, S. Protected areas, and biodiversity: An overview of key issues. In: World Conservation Monitoring Centre, and Convention on Biological Diversity of the United Nations Environment Program, Cambridge, UK, and Montreal, Canada. 2004.

Pureza, F.; Pellin, A.; Padua, C. Unidades de conservação: fatos e personagens que fizeram a história das categorias de manejo. São Paulo: IPÊ e Matrix Editora, 2015.

Silva, J. S.; Vieira, M. D. G.; Veras, G. Gestão de Unidades de Conservação: um estudo de caso na Área de Proteção Ambiental da Serra de Baturite-CE. Revista Brasileira de Gestão Ambiental e Sustentabilidade, 1 (1), 23-33, 2014.

Souza, M. F.R. Política pública para unidades de conservação no Brasil: diagnóstico e propostas para uma revisão. Rio de Janeiro: Lumen Juris, 2014.

VALE, M. M.; BERENGUER, E.; de MENEZES, M. A.; de CASTRO, E. B.; de SIQUEIRA, L. P.; PORTELA, R. C. Q.; The COVID-19 pandemic as an opportunity to weaken environmental protection in Brazil. Biological Conservation, 255, 1-5. 2021.

VALLEJO, L. R. Tempo, espaço e contradições na proteção das áreas naturais: As políticas públicas e a conservação ambiental no Estado do Rio de Janeiro (1975 a 2002). Niterói: Editora Alternativa, 2017.

WWF - World Wide Fund for Nature. Observatórios de UCs da WWF. APAs: O elo fraco da proteção. 2015. Disponível em: <observatorio.wwf.org.br/blog/2015/03/04/apas-o-elo-fracoda-protecao/>. Acesso em: nov. 2015.

\section{Authorship contributions}

\section{1 - Carlos André Luz Jeronymo}

Environmental Engineer, Master's in environmental engineering http://orcid.org/0000-0002-8814-0176•carlosjeronymo@gmail.com Contribuition: Head Researcher 


\section{2 - Elmo Rodrigues da Silva}

Environmental Engineer, Master's in Environmental Engineering https://orcid.org/0000-0002-1214-3151·elmo.slv@gmail.com

Contribuition: Co-Researcher

\section{3 - Kenny Tanizaki Fonseca}

Environmental Geochemist, Master's in Environmental Geochemistry https://orcid.org/0000-0003-4670-4567 • kenny.fonseca@gmail.com Contribuição: Co-Researcher

\section{How to quote this article}

JERONYMO, C. A. L.; SILVA, E. R.; FONSECA, K. T. The Environmental Protection Areas tragedy: an analysis of the implementation of Nature Conservation Units, Brazil. Ciência e Natura, Santa Maria, v. 43, e86, 2021. Available in: https://doi.org/10.5902/2179460X64612. 